\title{
Aldo Čavić
}

\section{Hvarska renesansna intelektualna polja}

Izvorni znanstveni rad

Research paper

UDK 316.7-057.85

https://doi.org/10.32728/tab.17.2020.3,

$U$ radu se razmatraju književne i intelektualne veze hvarskih renesansnih književnika unutar dalmatinske res publica litteraria. Temeljeći se na teorijskim postavkama P. Bourdieaua konstruiraju se dva hvarska intelektualna polja koja djeluju od početaka do sedamdesetih godina XVI. st. U tim poljima uočavaju se centralne ličnosti, prevladavajuće književne ideje i obrisi intelektualnih preokupacija u svjetlu promjena duha vremena prije i nakon Tridentskoga koncila. Naznačuje se i latinističko protopolje oko talijanskoga humanističkog učitelja Tidea Acciarinija, te u dodatku, u svjetlu novootkrivene knjige soneta Hanibala Lucića, talijansko intelektualno polje oko toga hvarskog književnika.

Ključne riječi: Hvar, renesansa, poslanice, dalmatinska res publica litteraria, intelektualna polja

\section{UVOD}

Dalmatinske su komune u XVI. stoljeću (kao i kroz cijelo razdoblje vladavine Mletačke Republike, do njenog kraja 1789. godine) bile zasebni politički organizmi, međusobno neovisne političke jedinice, a njeni su stanovnici osjećali komunu kao jedinu domovinu. ${ }^{1}$ $\mathrm{U}$ toj svojoj jedinoj domovini članovi komune bili su već od XIV. stoljeća jasno i nepremostivo podijeljeni u dvije društvene skupine, dva staleža - plemiće i pučane. Pučani nikada, do kraja postojanja

1 „U strukturi imena mletačkih 'Schiavona' naziv grada bio je, dakle, temeljnim znakom pripadnosti. Samo je grad mogao biti 'domovinom'." (Raukar 1997: 187). 
Sinjorije, nisu uspjeli participirati u istinskoj vlasti komune - Velikome vijeću. Upravo se zbog toga Neven Budak odvažio uobičajeni naziv među hrvatskim historiografima za ta gradska društva Dalmacije - komune - zamijeniti pojmom koji bolje određuje njihovu političku strukturu - aristokratske republike. ${ }^{2}$ Sastojale su se od grada (a to je značilo ono mjesto koje je bilo omeđeno gradskim zidom i u kojemu je stolovao biskup) i njegovog distrikta, teritorija. Gradske elite dijelile su se na sekularne i crkvene. Crkvenu elitu činili su nadbiskupi, biskupi, članovi kaptola, priori samostana. Sekularnu elitu može se podijeliti u tri osnovna tipa: političku, koju su činili isključivo plemići i djelomično stranci - najčešće Mlečani, koji su obnašali neke od najvažnijih dužnosti lokalne vlasti (knez, kamerlengo, kaštelan); ekonomsku, u kojoj su pored plemića-velikih zemljoposjednika, sudjelovali i pučani obogaćeni trgovinom i poljoprivredom; i intelektualnu, koju su činili notari, kancelari, učitelji, školovani najčešće u Padovi, a u kojoj su mogla participirati oba staleža. ${ }^{3}$ Samo je među plemićima bilo pojedinaca koji su u sebi objedinjavali sve te tri kategorije elitizma: vlast, bogatstvo i obrazovanost. Najizrazitiji predstavnici te istinske elite na Hvaru bili su plemići književnici. ${ }^{4}$

lako su te aristokratske republike bile jedine prave domovine njihovih stanovnika, postojao je širi društveni prostor u osnovi čijega su integracijskog procesa bili ljudi, njihove veze i bliskosti duhovnih struktura. Tomislav Raukar taj širi prostor društvene srodnosti pojedinaca dijeli na dva glavna sloja integrativnih procesa: onaj veći koji zove „jadranski društveni prostor” i koji se ostvaruje na cijelom Jadranu - i hrvatskom i talijanskom, i onaj uži - „istočnojadranski”. ${ }^{5}$ Taj prostor istočne obale Jadrana, zemlju Schiavona, čine društva malih aristokratskih republika Mletačke Dalmacije i jedne velike aristokratske republike - Dubrovačke Republike, kao posebne, nezavisne političke tvorevine. Najviše je istraživan društveni prostor istočnoga Jadrana koji su stvorili svojom intelektualnom djelatnošću, vezama i komunikacijama plemići Dubrovnika, Zadra, Splita, Hvara, Šibenika i Trogira, a najočitiji je u kreiranju prostora humanističke i

2 Budak 1997: 190.

3 Idem: 187-188.

4 Svi danas poznati hvarski književnici renesanse bili su plemići. Izuzetak na kraju stoljeća je Benetović, dok je Pribojević pripadao crkvenoj eliti. Najpoznatiji književnici dolaze iz najbogatijih plemićkih porodica, kao što su to Hektorović, Lucić ili Paladinić.

5 Raukar 1997: 378-379. 
renesansne književnosti. ${ }^{6}$ Taj društveni prostor nazovimo imenom res publica litteraria, koje se logično nastavlja na pojam aristokratske republike. Ta „književna republika” ili „republika slova” nadilazila je uske granice komuna - domovina, ali i staleške podjele unutar komuna - u njoj su ravnopravno sudjelovali književnici plemići i pučani. Kao svaka republika, imala je među članovima hijerarhijsku ljestvicu i uloge koje su pojedini članovi „republike” zauzimali. Istraživati taj društveni (duhovni, intelektualni, ali zahvaljujući vezama i komunikacijama unutar njega i vrlo stvarni) prostor dalmatinske književne republike najadekvatnije je u svjetlu teorije francuskoga sociologa i filozofa Pierra Bourdieua o intelektualnim i kulturnim poljima.

Bourdieu polazi od premise da su u svakom činu intelektualnog $i$ umjetničkog (u našem slučaju književnoga) stvaranja skrivene veze između stvaratelja i njegovoga djela, uvjetovane društvenim odnosima unutar kojih se događa stvaralački čin kao čin komunikacije, odnosno da je samo djelo uvjetovano položajem stvaratelja u intelektualnom polju. ${ }^{7}$ Javni smisao djela (kao kolektivno ustanovljen sud o vrijednostima $i$ istini djela) stvaratelju postaje jasan tek u odnosima između njega i pripadnika intelektualnoga polja, a sam takav smisao rezultat je složenih interakcija između intelektualnih činova donošenja sudova. ${ }^{8}$

Struktura intelektualnoga polja međuzavisna je s jednom od osnovnih struktura kulturnoga polja - strukturom kulturnih (u našem slučaju književnih) djela svrstanih po stupnju legitimnosti. U određenom društvu u određenom vremenskom trenutku sva kulturna djela ne uživaju isti ugled, nemaju istu vrijednost i ne traže jednako hitnu reakciju na

\footnotetext{
6 Budak u svom radu o gradskim elitama tek dotiče pitanje intelektualne aktivnosti plemića. Zaključuje da tek predstoje istraživanja o njihovom sudjelovanju, kao posebne grupe, u stvaranju humanističke i renesansne književnosti, jer da su dosadašnja istraživanja gledala tu aktivnost isključivo kao dio kulture grada ili nacije (Budak 1997: 195).

7 Bourdieu 1970: 74. I nastavlja: „Položaj stvaraoca u strukturi intelektualnog polja, [...] svaki od njih određen je svojim pripadanjem ovom polju: u stvari, zahvaljujući posebnom položaju, koji u njemu zauzima, on dobija poziciona svojstva, koja su nesvodljiva na unutrašnja svojstva, a naročito dobija određeni tip participacije u kulturnom polju kao sistemu odnosa između tema i problema i, samim tim, određeni tip kulturnog nesvesnog, istovremeno u sebi sadržavajući ono što ćemo nazvati funkcionalnom težinom, jer se njegova sopstvena 'masa', to jest njegova moć (ili, bolje rečeno, njegov autoritet) na tom polju ne može definisati nezavisno od njegovog položaja u tom polju.“ (idem: 75).
} 
njihovo pojavljivanje. ${ }^{9}$ Kad govorimo o (vrijednosnoj) hijerarhiji književnih djela u kulturnom polju, moramo misliti i na hijerarhiju unutar intelektualnoga polja. Intelektualac, stvaratelj određuje se povijesno i društveno kao dionik intelektualnoga polja unutar kojega se njegova stvaralačka zamisao definira i konstituira. On je uvijek suvremenik onih kojima se obraća svojim djelom i s kojima komunicira, implicitno prihvaćajući zajednički im kodeks tema, problema, načina mišljenja, oblika percepcija. Uvijek je dio neke kulture, prostora, epohe (povijesnoga razdoblja), ili klase (staleža). ${ }^{10}$ On i njegovo djelo uvijek su dio neke strukture kulturnoga polja.

Primjenjujući Bourdieuove kategorije možemo dalmatinsku književnu republiku promatrati dvojako: ona je svojevrsno kulturno polje, čija je struktura određena književnim djelima svrstanim po stupnju legitimnosti. Unutar toga kulturnog polja djeluje intelektualno polje koje čine humanisti i književnici dalmatinskih komuna. Između ta dva polja postoji interakcija: položaj nekoga književnika unutar intelektualnoga polja određuje položaj njegovoga djela u kulturnom polju. Istodobno, položaj djela u kulturnom polju utječe na položaj književnika u intelektualnom polju.

Istražiti odnos i položaj književnika i djela u tim međusobno isprepletenim poljima moguć je kroz oblik književnosti kojima je intelektualna elita Mletačke Dalmacije i Dubrovačke Republike međusobno komunicirala - poslanicama. Hvarski književnici upućivali su i primali poslanice unutar dalmatinske književne republike. Poslanice je moguće analizirati s više komunikacijskih aspekata: brojnost upućenih pojedinom književniku, prostor s kojega dolaze poslanice, način obraćanja između pošiljatelja i adresata (s time da ovdje uvijek treba uzimati u obzir konvencije vremena i konvencije književne forme), zatim opis i vrijednosni sudovi o prostoru ili skupini prema kojima je poslanica upućena. Vjerujemo da je tako moguće odrediti položaj hvarskih književnika u intelektualnom polju dalmatinske književne republike, kao i položaj njihovih djela unutar kulturnoga polja toga društvenog prostora. Također se u tim poslanicama sama hvarska komuna, Hvar kao domovina tih književnika, kao jedna od njihovih bitnih identitetskih odrednica, pojavljuje kao slika, predodžba, vrijednosni sud. Naša analiza lučit će ove elemente u poslanicama

9 Idem: 92.

10 Idem: 99. 
i u rijetkim posvetama kojima književnici namjenjuju ili zavješćuju pojedina svoja djela. Temeljem takve analize pokušat ćemo konstruirati intelektualno polje promatranoga vremena i prostora, a naročito participaciju hvarskih književnika unutar njega, njihov položaj unutar toga polja. Također će se ovom analizom konstruirati slika, predodžba Hvara u kulturnom polju dalmatinske res publica litteraria.

\section{POSLANICE KAO OBLIK KOMUNIKACIJE UNUTAR INTELEKTUALNOGA POLJA DALMATINSKE KNJIŽEVNE REPUBLIKE}

Za potrebe ovoga rada rabit će se prije svega „komunikacijski potencijal" te specifične književne vrste, književnog žanra koji se javlja vrlo rano, još u antici, a u doba humanizma i renesanse doživljava i vlastitu renesansu. ${ }^{11}$ Bez obzira je li pisana u stihu (što je za promatrano razdoblje gotovo pravilo) ili u prozi, ${ }^{12}$ karakterizira je izravno obraćanje adresatu i dominantni autobiografski ili biografski elementi. „Poslanica kao književni žanr po svojim je specifičnim uvjetima komunikacije s jedne strane obilježena autobiografičnošću, a s druge zbog svoje apelativnosti (obraćanje sugovorniku) i racionalističke utemeljenosti (dijalog s nekim) pruža prostor za iskazivanje stavova, mišljenja i koncepcija o životu, društvu, umjetnosti i književnosti." ${ }^{13}$ Taj potencijal poslanica upravo je ono što nam treba da bismo konstruirali intelektualna polja XVI. stoljeća. lako se unutar te književne vrste mogu uočiti razne podvrste grupirane po tematici ${ }^{14}$

11 O poslanicama kao književnom žanru, a posebno o renesansnim poslanicama u hrvatskoj književnosti, određujući im korpus i klasificirajući ih na temelju poetičko-estetičkih iskaza, koristeći dotadašnju važniju literaturu o toj temi, napisala je opširan rad Dunja Fališevac: „Renesansna poslanica kao prostor poetičko-estetičkih iskaza”, u Colloquia Maruliana, 17, Split 2008, str. 7-25. Tim radom služimo se kao osnovnim pogledom na taj, za renesansu vrlo važan, književni žanr.

\footnotetext{
12 Osnovnu podjelu na stihovane i prozne poslanice preuzima i Fališevac, naglašavajući da je u stihovanim poslanicama hrvatske renesansne književnosti dominantna njihova „pohvalnička funkcija” (Fališevac 2008: 15), kao i to da su one „mnogo važnije kao izvor autobiografskih, biografskih ili bibliografskih podataka ili, u slučajevima u kojima su sačuvana i inicijalna pisma i odgovori na njih (a to je slučaj s Nalješkovićem i njegovim korespondentima), kao izvor podataka o književnim krugovima u kojima su pojedini pisci djelovali i unutar kojih su prijateljevali” (idem: 11). Prozne poslanice u koje ubraja i predgovore-posvete posebno klasificira u pet kategorija s obzirom na poetičko-estetičke iskaze i namjere u njima.

13 Idem: 8.

14 „Tako tematikom poslanica može biti vrlo različita: u njoj se pojavljuju društvenopolitički, povijesni, filozofski, moralni, književnokritički, estetički, satirički, autobiografski, biografski sadržaji” (ibidem).
} 
ili po tonu ${ }^{15}$, za naše istraživanje to nije važno. Želimo ih promatrati samo kao oblik komunikacije unutar članova intelektualnoga polja, te iz načina obraćanja između pošiljatelja i primatelja, učestalosti, redoslijedu upućivanja (odgovor) ili spominjanja trećega člana unutar poslanice (kao, recimo, prenošenje pozdrava ili isticanje vrijednosti nekoga trećeg književnog djela) pokušati stvoriti što uvjerljiviju sliku književnih komunikacija i hijerarhijskoga položaja sudionika komunikacije. Subjekt se u njima iskazuje „više nego u nekim drugim žanrovima - kao povijesno postojeća osoba i može se nazvati povijesni iskazni subjekt.”"16 Taj su „povijesni iskazni subjekt” u našim slučajevima književnici Hvara i dalmatinskih komuna s kojima oni komuniciraju, povijesne osobe o kojima i izvan poslanica postoje razni dokumenti kojih ih situiraju u prostoru i vremenu - stvarni ljudi jednoga vremena. Kroz poslanice koje nazivaju knjigom, listom ili pismom ${ }^{17}$ grade specifičnu mrežu komunikacija i određuju se u međusobnim odnosima. Čitajući u njima te odnose možemo konstruirati intelektualna polja u kojima su sudionici.

Ono čime raspolažemo ipak su samo reliquiae reliquiarum jednoga vremena i jednoga prostora, te zaista moramo uvijek imati na umu da ta rasuta bašćina ne može biti pouzdana slika XVI. stoljeća. Da bi slika ipak bila što preciznija, uključit ćemo u korpus književne komunikacije i neke tekstove koji nisu poslanice u užem smislu riječi, poput nadgrobnica.

\section{KORPUS TEKSTOVA KNJIŽEVNE KOMUNIKACIJE UNUTAR HVARSKIH INTELEKTUALNIH POLJA}

Termin hvarsko intelektualno polje koristimo da bismo ga razlikovali od hvarskoga književnog kruga jer je po strukturi puno širi nego već davno udomaćeni termin „hvarski književni krug”. Dok hvarski književni krug obuhvaća samo hvarske književnike koji djeluju tijekom XVI. stoljeća, hvarsko intelektualno polje je tehnički termin koji obuhvaća cjelinu društvenoga prostora u kojem osim hvarskih književnika participiraju i oni iz drugih dalmatinskih gradova s kojima Hvarani komuniciraju i s kojima tvore intelektualno polje u određe-

15 „Različita je i po tonu: kreće se u rasponu od elegičnog do oštrog, poantiranog i satiričnog, familijarnog i ceremonijalnog, te stoga u blizini elegije isto tako i satire, a može biti pretežito lirska kao i epska” (ibidem).

16 Idem: 7.

17 „I samostalne poslanice i predgovore - posvete svojim djelima stari su hrvatski pisci nazivali knjigom, listom ili pismom, a i književni povjesničari obje ove vrste tekstova najčešće nazivaju poslanicom.” (idem: 9). 
nom vremenskom isječku. Kako je XVI. stoljeće dug period u kojem su se izmijenile barem četiri generacije (ovo računamo po jednostavnoj i samorazumljivoj logici da se tijekom stoljeća svakih 25 godina stvara nova generacija), u kojem su se mijenjale društvene okolnosti, književne mode, prekidali lanci komunikacije, umirali stari i rađali novi književnici, neki književnici jednostavno prestajali pisati, kako je to bilo burno stoljeće koje ni po čemu nije bilo isto na početku i na kraju, možemo pretpostaviti da ćemo uočiti barem dva takva hvarska intelektualna polja. Ali, o tome ćemo pisati u zaključnim razmatranjima nakon što najprije prikažemo korpus komunikacijskih tekstova.

Tekstove navodimo kronološki, upravo radi mogućnosti uočavanja više intelektualnih polja koja djeluju u raznim vremenskim isječcima XVI. stoljeća. Kronologiju stvaramo uvjetno, jer svi tekstovi nisu datirani. Najlakše je s onim poslanicama koje završavaju datumom pisanja. Za datiranje drugih koje to nemaju koristimo se posrednim datacijama, npr. godinom smrti primatelja kao terminus post quem non, ili godinom pisanja poslanice prema kojoj je ta nedatirana odgovor. Za neke uzimamo već ustaljene datacije iz povijesti književnosti. Ne možemo tvrditi da je kronologija apsolutna, ali pokušavamo je učiniti što preciznijom.

Koristit ćemo se hrvatskim, latinskim i talijanskim tekstovima jer je „književna republika” XVI. st. bila trojezična. Latinske i talijanske tekstove donosimo u hrvatskom prijevodu (skraćenicama lat. i tal. označavamo izvorni jezik na kojemu su napisani).

Uz svaki tekst navodimo autora, adresata, godinu pisanja, mjesto odakle je upućena i mjesto kamo je upućena, te izvor iz kojega ga preuzimamo.

\section{PRVI DIO KORPUSA}

1. Frane Božićević Natalis > Pavlu Paladiniću (1496.), Split > Napulj (?), lat. ${ }^{18}$

2. Marko Marulić > Hanibalu (Luciću) (prvo desetljeće XVI. st.), Split > Hvar, lat. ${ }^{19}$

3. Marko Marulić > Katerinu (Gazaroviću?) (prvo desetljeće XVI. st.), Split > Hvar, lat. ${ }^{20}$

18 Franc(iscus) Nat(alis) (Graciotti 2005: 181).

19 Ad Phoebum pro Hannibale iuuene poetice studioso (Petrić 1998: 215-224).

20 Ad Caterinum poetam Pharensem (idem: 222). 
4. Frane Božićević Natalis > Hanibalu Luciću (možda drugo desetljeće XVI. st.), Split > Hvar, lat. ${ }^{21}$

5. Hanibal Lucić $>$ Franu Božićeviću Natalisu (možda drugo desetljeće XVI. st.), Hvar > Split ${ }^{22}$

6. Hanibal Lucić $>$ Nikoli Albertiju Matuliću (možda drugo desetljeće XVI. st.), Hvar > Split ${ }^{23}$

7. Hanibal Lucić > Jeronimu Martinčiću (1519.), Hvar $>$ Split ${ }^{24}$

8. Hanibal Lucić $>$ Jeronimu Martinčiću (oko 1520.), Hvar $>$ Split $^{25}$

9. Hanibal Lucić $>$ Francisku Paladiniću (oko 1520.), Hvar $>\mathrm{Hvar}^{26}$

10. Hanibal Lucić $>$ Milici Jeronima Koriolanovića (možda drugo desetljeće XVI. st.), Hvar > Trogir ${ }^{27}$

11. Hanibal Lucić $>$ Jeronimu Martinčiću (1522.), Hvar $>$ Split ${ }^{28}$

12. Hanibal Lucić > Jeronimu Martinčiću (prije 1525., možda 1523.), Hvar > Split ${ }^{29}$

13. Hanibal Lucić > Jeronimu Martinčiću (prije 1525.), Hvar > Split ${ }^{30}$

14. Hanibal Lucić > nadgrobnica Jeronimu Martinčiću (oko 1525.) ${ }^{31}$

15. Hanibal Lucić $>U$ pohvalu grada Dubrovnika (možda treće desetljeće XVI. st.) ${ }^{32}$

16. Jeronim Bartučević > Mikši Pelegrinoviću (možda treće desetljeće XVI. st.), Hvar > Hvar, lat. ${ }^{33}$

21 Ad Annibalem Lutium (Marković 1958).

22 Francisku Božićeviću (Frangeš 1968': 112-113).

23 Nikuli Matuliću (idem: 114).

24 Pariž Eleni, Jeronimu Martinčiću pozdravljenje (idem: 133-134).

25 Jeronimu Martinčiću (idem: 115-116).

26 Anibal Lucij Francisku Paladiniću pozdravljenje (idem: 63).

27 Milici Jeronima Koriolanovića (idem: 117-123).

28 Pisni razlicim prijateljem Jeronimu Martinčiću (idem: 102-109).

29 Istomu Jeronimu (idem: 110-111).

30 Jeronimu Martinčiću (idem: 126-131).

31 Nadgrobnica Jeronima Martinčića, splitskog vlastelina (idem: 132).

32 U pohvalu grada Dubrovnika (idem: 97-101).

33 Ad Michaelem Peregrinum dicentem se in visione amicae felicem Hieronymus Bertucius Atticus (Jeronim Bartučević Atik Mikši Pelegrinoviću, koji tvrdi da ga usrećuje pogled na ljubljenu ženu) (Novaković 2001: 6). 
17. Petar Hektorović $>$ Mikši Pelegrinoviću (1528.), Hvar $>\mathrm{Hvar}^{34}$

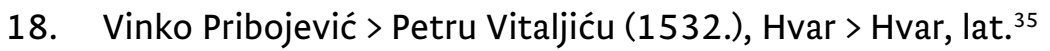

\section{PRVO HVARSKO INTELEKTUALNO POLJE}

Izlazak prve tiskane knjige hvarske književnosti XVI. stoljeća - Pribojevićeva govora O podrijetlu i slavi Slavena tiskanog 1532. u Veneciji - uzimamo kao simboličnu granicu. Čini se da se pomalja prvo hvarsko intelektualno polje. Prva sljedeća poslanica pojavljuje se tek 1539. godine i dolazi kao odgovor na Hektorovićevu poslanicu upućenu Vetranoviću. Hektorović otvara novi „komunikacijski kanal” prema Dubrovniku. Dubrovački pisci ne sudjeluju u tom prvom hvarskom intelektualnom polju. Lucićeva pjesma u pohvalu Dubrovniku (na koju su se Dubrovčani oglušili), te mnogo godina prije Lucića, devedesetih godina XV. stoljeća, razmjena latinskih pohvalnica između Paladinića i Crijevića, jedini su tragovi veza s Dubrovnikom. Najaktivniji sudionik u komunikaciji unutar toga polja je Hanibal Lucić. Njemu su upućene poslanice značajnijih članova „Marulićeve ekipe” (kako ih zove Neven Jovanović) - samoga Marulića, Božićevića Natalisa i Jeronima Martinčića (za kojega to znamo po Lucićevim odgovorima). On sam intenzivno komunicira s Martinčićem, a upućuje poslanice i Božićeviću i Matuliću Albertiju. Hektorović i Bartučević samo se uzgredno spominju u toj komunikaciji. Pelegrinović, koji je najmlađi od četverolista hvarskih književnika o kojima govori Pribojević 1525. (ili možda točnije 1532. godine, jer on svoj govor prilagođava za tisak i nismo sigurni u sadržaj onoga što je izgovorio u Hvaru), pojavljuje se u latinskom epigramu Bartučevića i u Hektorovićevoj posveti prijevoda Ovidija. Ali, Jeđupka je već napisana i dobiva prve pohvale (Hektorović).

Najraniji trag o vezama Hvarana i Splićana je latinska pjesma pohvalnica Božićevića Natalisa upućena 1496. Pavlu Paladiniću. Pavao Paladinić je poseban slučaj, a oko toga prvog poznatog hvarskog pjesnika, koji, po svemu se čini, nije pisao na hrvatskom jeziku, može se konstruirati svojevrsno latinističko intelektualno protopolje, temeljeno na pjesmama sačuvanim u njegovom rukopisnom kanconijeru iz 1496. godine. Naime, osim Božićevićeve pohvalnice, na kraju njegovog kanco-

34 Plemenitomu i svake časti dostojnomu gospodinu Mikši Pelegrinoviću, vlastelinu hvarskomu, Petar Hektorović milo pozdravljenje s priporučenjem p. (Frangeš 1968: 249-250).

35 Fra Vinko Pribojević, Hvaranin, Dalmatinac, profesor svete teologije, dominikanac, najsrdačnije pozdravlja Petra Vitaljića, hvarskog patricija zapovjednika galije, svog najboljeg prijatelja (Pribojević 1997: 128-129). 
nijera su i pohvalnice dvojice istaknutih humanista: Dubrovčanina llije Crijevića $^{36}$ (Dubrovnik, 1463. - 1520.) i talijanskoga humanista, koji je kao učitelj proveo u Dalmaciji gotovo dvadeset godina, Tidea Acciarinija ${ }^{37}$ Sant'Elpidio a Mare, Italija, između 1427. i 1430. - ?, oko 1500.). Crijevićeva pjesma svojevrsni je odgovor na Paladinićevu latinsku pjesmu od četiri elegijska distiha naslovljenu lliji Crijeviću, najvećem latinskom pjesniku humanizma u Dubrovniku, u kojoj je, osim pohvale, i pokušaj utjehe Crijeviću da lakše podnese šest mjeseci u zatvoru zbog uvrede punice. Kako je Crijević u zatvoru bio 1491., pjesma bi se mogla datirati u to vrijeme. ${ }^{38}$ Prisustvo Acciarinija u tom Paladinićevom kanconijeru intrigantnije je i otvara mnoga pitanja o utjecajima toga Talijana na razvoj (i) hvarske humanističke poezije. Naime, Tideo Acciarini već je 1461. ili 1462. godine učitelj u Splitu, a najpoznatiji mu je učenik Marko Marulić. Između 1465. i 1466. posjetio je u Šibeniku Jurja Šižgorića, a čini se da je već 1472 . godine prešao u Dubrovnik, gdje ostaje do 1480 ., kada napušta Dalmaciju. U Dubrovniku je učitelj svim najpoznatijim dubrovačkim humanistima (Iliji Crijeviću, Ludoviku Crijeviću Tuberonu, Karlu Puciću, Luki i Jakovu Buniću, Ivanu Gučetiću i dr.). Čini se da je posljednje godine života, one kada je nastala i ta pjesma posvećena Paladiniću, proveo na španjolskom dvoru kao učitelj princa Juana od Asturije, sina kralja Ferdinanda Katoličkoga. ${ }^{39}$ Njegovo je ime i djelovanje povezano, kako se vidi, s najpoznatijim i najznačajnijim prvim hrvatskim humanistima i latinistima. Što u tom kontekstu znači pjesma posvećena Paladiniću? lako je prošlo već 16 godina da je Acciarini napustio Dalmaciju, Paladinić mu šalje svoj kanconijer na ogled. Je li Acciarini i nakon napuštanja Dalmacije zadržao kontakte s hrvatskim humanistima? Možemo li pretpostaviti da mu je i Pavao Paladinić bio učenik u humanističkoj školi u Splitu, pa svome učitelju šalje kanconijer na ogled? lako odgovore na ta pitanja ne možemo sa sigurnošću dati, možemo uočiti to prvotno hvarsko humanističko protopolje koje čine četvorica latinista: Pavao Paladinić, Frane Božićević, llija Crijević i Tideo Acciarini (v. kartu 1).

36 Latinska pjesma naslovljena Aelius Lampridius Cervinus Pau(lo) Pall(adino) suo koju je Ilija Crijević uputio Paladiniću u čast, veličajući Paladinićevo pjesničko umijeće i koristeći se brojnim antičkim motivima, bogovima i muzama. Nastala je 1496. kada je kanconijer završen (Graciotti 2005: 178).

37 Latinska pjesma naslovljena Tydeus Acciarinus od dvadeset i jednog heksametra, koncipirana kao dijalog između muze Klio i autora Acciarinija. U posljednjim stihovima Paladinić se opisuje kao dostojan potomak Demetrija Farskog. To je prvo poznato spominjanje znamenitog antičkog Hvaranina, grčko-ilirskoga vojskovođe iz početka III. st. prije Krista (idem: 181 ).

38 Pjesma ima naslov Ad Eliu(m) Ceruinu(m) (idem: 162), a v. i Graciotti 2006: 62. 
Ali, Paladinić pretežno živi u Italiji, odnosno plovi na hvarskoj galiji čiji je zapovjednik, a na Hvaru su samo ona slavna četvorica književnika $i$ nepoznati pjesnik - mladac Katerin kojemu recenziju prvih stihova upućuje Marulić. Iz mraka povijesti pojavljuju se još dvojica Hvarana, obojica vrlo bogati plemići, pripadnici najbogatijih hvarskih porodica - Frane Paladinić i Petar Vitaljić, ali oni se ne bave književnim radom. Javlja se i jedna Trogirka, obrazovana i vješta u izradi goblena, u koju je Lucić izgleda bio zaljubljen. Ako zanemarimo tu trogirsku vezu, i nekakav dodir Hvara i Dubrovnika u razmjeni latinskih pjesama Paladinića i Crijevića, onda vidimo da se sva komunikacija odvija na relaciji Hvar Split i na samom Hvaru. U centru toga polja je Hanibal Lucić. Svi sudionici su bogati plemići, s hvarske strane oni najbogatiji. Izuzetak je Pribojević, ali i on pripada eliti - crkvenoj. Ovidije je najpopularniji pisac od starih, prevode ga Lucić i Hektorović, koristi Bartučević u latinskom epigramu Pelegrinoviću, a Pelegrinović ga sigurno dobro poznaje da bi mogao prepoznati Bartučevićeve književne aluzije. U intertekstualnom diskursu Ovidije je zvijezda: prepoznajemo ga i u Lucićevoj poslanici Martinčiću, gdje ga Lucić i Bartučević nagovaraju da prevede na hrvatski dio Ovidija, onako kako je Ovidijev prijatelj Sabin odgovarao na prijateljeve radove. Kršćanske tekstualnosti ovdje gotovo da nema. Izuzetakje ona neobična, pokornička pjesma Hanibala Lucića Od Božićne noći, ali ona izgleda kao oproštaj Lucića od bavljenja grišnim stvarima, možda i književnošću (na hrvatskom jeziku). Lucićev ciklus od šest talijanskih soneta upućenih mletačkim upraviteljima u Dalmaciji, kojima želi „,barem stvoriti iluziju da pripada onovremenoj eliti, da razgovara s uglednicima i moćnicima"40, nastao vjerojatno od sredine do kraja tridesetih godina XVI. st. kao „primjer 'primijenjenoga' pjesništva”" , znak je ugasloga pjesničkog nadahnuća. ${ }^{42} U$ njima se Lucić koristio repertoarom imena i simbola iz antičkoga svijeta ${ }^{43}$, pa i po tome pripadaju tom

40 Maroević 1987: 246.

41 Ibidem.

42 Objavljujući ih u originalu prvi put nakon 1874. godine (tada ih je objavio Franjo Rački u SPH, VI, JAZU, po jednom kasnijem prijepisu iz prvog izdanja Lucićevih Skladanja izvarsnih pisama razlicih) i prevodeći ih na hrvatski, Tonko Maroević je taj ciklus talijanskih soneta (iako „sasvim konvencionalnog karaktera i jedva prosječnog dometa”, idem: 236) vratio u okrilje „,hrvatske kulturne baštine”, ističući da se „odskora ne samo latinska pismenost, nego i talijanska, njemačka, mađarska i njima slične smatraju s pravom konstitutivnim dijelom hrvatske kulturne baštine” (idem: 237).

43 „Ako je indeks imena i literarnih, 'učenih' prisjećanja iznimno velik u svim Lucićevim stihovima, a posebno onima izvan petrarkističkog, 'leutaškog' okvira, talijanski se soneti u tom pogledu približavaju čak suvremenoj im latinističkoj produkciji, iskićenoj i 'začinjenoj' brojnim sintagmama i simbolima grčko-rimskog supstrata i porijekla" (idem: 245). 
prvom intelektualnom polju u kojemu humanistički diskurs prevladava. Ono što slijedi sredinom XVI. stoljeća imat će sasvim druge tonove.

Prije nego što nastavimo pratiti korpus „komunikacijskih tekstova” hvarskoga XVI. stoljeća, istaknimo još jednom povijesni događaj koji nam se čini ključan za usmjeravanje „komunikacijskoga lanca” prema Dubrovniku. Strašna epidemija kuge u Splitu 1526. - 1527. godine, dvije godine nakon smrti centralne figure splitskoga književnog kruga Marka Marulića, a otprilike u vrijeme smrti dva brata Martinčića (za jednog od njih, Franu Martinčića, znamo da je žrtva kuge ${ }^{44}$ ), velika je povijesna prekretnica za Split. lako ima različitih vijesti o broju žrtava, ${ }^{45}$ činjenica je da se Split nije oporavio ni do sredine XVI. stoljeća, jer mletački izvjestitelj Zan Battista Giustinian navodi da 1553. u Splitu živi samo 2490 stanovnika i da ima samo 16 siromašnih plemićkih obitelji. ${ }^{46} \mathrm{U}$ isto vrijeme u Dubrovniku živi 30000 stanovnika i centar je književne, ali i gospodarske aktivnosti. Razumljivo je da hvarski književnici priznanje sada traže u prosperitetnom i živahnom Dubrovniku, časti našega jezika (v. karte 2 i 3).

44 Jovanović (2006: 10-25) donosi sadržaj nadgrobnice koju je Frano Božićević Natalis sastavio povodom smrti Frana Martinčića u kojoj govori da, „kada je domovinu snašla kuga, Frane se izložio opasnosti da bi ju spasio", ali je i sam postao žrtva.

45 Jovanović (2006: 3-25) govori o 6000 žrtava u Splitu i okolici, a Raukar (1997: 174) navodi: „Ali da su epidemije katkad teško pogađale gradska društva, svjedoči kužna epidemija u Splitu godine 1526/1527: broj splitskog stanovništva smanjen je od oko 5.000 (1525) na samo nešto više od 2.00o".

46 Šimunković 2011: 55. 


\section{DRUGI DIO KORPUSA}

19. Mavro Vetranović $>$ Petru Hektoroviću (1539.), Dubrovnik $>\mathrm{Hvar}^{47}$

20. Nikola Nalješković $>$ Petru Hektoroviću (1540.), Dubrovnik $>\mathrm{Hvar}^{48}$

21. Petar Hektorović $>$ Nikoli Nalješkoviću (1541.), Hvar $>$ Dubrovnik ${ }^{49}$

22. Nikola Nalješković $>$ Petru Hektoroviću (1541.), Dubrovnik $>\operatorname{Hvar}^{50}$

23. Nikola Nalješković > Petru Hektoroviću (poslije 1541.), Dubrovnik $>$ Hvar $^{51}$

24. Antun Rozanović > (Petru Hektoroviću) Nikoli Nalješkoviću (poslije 1546.), Korčula > Dubrovnik, lat. ${ }^{52}$

25. Ludovik Paskalić $>$ Hanibalu Luciću (prije 1549.), Kotor $>$ Hvar, tal. $^{53}$

26. Ludovik Paskalić $>$ Jeronimu Bartučeviću (prije 1551.), Kotor $>$ Hvar, lat. ${ }^{54}$

27. Petar Hektorović > Jeronimu Bartučeviću (1552.), Stari Grad $>$ Hvar $^{55}$

28. Mavro Vetranović $>$ hvarskoj vlasteli (peto desetljeće XVI. st.), Dubrovnik $>\mathrm{Hvar}^{56}$

29. Petar Hektorović $>$ Graciozi Lovrinčevoj (možda peto ili šesto desetljeće XVI. st.), Stari Grad (?) > Hvar (Trogir(?)) $)^{57}$

30. Nikola Nalješković > Petru Hektoroviću (1555.), Dubrovnik $>$ Stari Grad ${ }^{58}$

47 Rešetar 1901: 206-215 (tekst pjesme 208-215).

48 Petru Hektoroviću, vlastelinu hvarskom (Nalješković 2005: 273-286).

49 Odgovor Nikoli Nalješkoviću (Frangeš 1968': 241-247).

50 Gospodinu Petri Hektoroviću odgovor Nikolin (Nalješković 2005: 288).

51 Guti gospodina Petra Hektorovića, vlastelina hvarskoga, Nikola Stjepka Nalješkovića Dubrovčanin piše (idem: 309).

52 Foretić 1970: 140.

53 Stipčević 2012: 18.

54 Novaković 2001: 6 i Gortan - Vratović 1969: 572.

55 Plemenitomu i velepoštovanomu gospodinu Hijeronimu Bartučeviću, vlastelinu hvarskomu, vitezu dostojnomu (Frangeš 1968': 234-235).

56 Vlasteostvu hvarskomu:

https://hr.wikisource.org/w/indeks.php?title=Vlasteostvu_hvarskomu\&oldid=50803.

57 Bogoljubnoj i svake hvale dostojnoj mladici Graciozi Lovrinčevi (Frangeš 19681: 226-231).

58 Gospodinu Petru Hektoroviću, vlastelinu hvarskomu, glas smrti Nikole Jerka Dmitrovića spjevaoca, koji umrije u Kandiji (Nalješković 2005: 299-300). 
31. Petar Hektorović > Jeronimu Bartučeviću (1556.), Stari Grad $>$ Hvar $^{59}$

32. Petar Hektorović > Mavru Vetranoviću (1556.), Stari Grad > Sv. Andrija ${ }^{60}$

33. Petar Hektorović > Mikši Pelegrinoviću (1557.), Stari Grad > Zadar $^{61}$

34. Nikola Nalješković > Petru Hektoroviću (1557.), Dubrovnik $>$ Stari Grad ${ }^{62}$

35. Mikša Pelegrinović > Sabu Bobaljeviću (1557.), Zadar > Dubrovnik ${ }^{63}$

36. Sabo Bobaljević > Mikši Pelegrinoviću (1557.), Dubrovnik > Zadar $^{64}$

37. Hortenzije Bartučević > Nikoli Nalješkoviću (oko 1560.), Hvar $>$ Dubrovnik $^{65}$

38. Nikola Nalješković > Hortenziju Bartučeviću (oko 1560.), Dubrovnik > Hvar ${ }^{66}$

39. Hortenzij Bartučević > Nikoli Nalješkoviću (oko 1560.), Hvar $>$ Dubrovnik $^{67}$

40. Nikola Nalješković > Ivanu Parožiću (oko 1560.), Dubrovnik $>$ Hvar $^{68}$

59 Petar Hektorović, Ribanje i ribarsko prigovaranje, Gospodinu Hijeronimu Bartučevi$c$ ću, vitezu poštovanomu, vlastelinu hvarskomu, Petre Hektorović ova ribarska prigovaranja za milošću i za razgovor šalje (Vončina 1986: 37).

60 Ocu i gospodinu hvale i časti veledostojnomu dom Mavru kalujeru, Dubrovčaninu (Frangeš 1968': 236-240).

61 Poštovanomu gospodinu Mikši Pelegrinoviću, vlastelinu hvarskomu, kančiliru zadarskomu (idem: 223-225).

62 Gospodinu Petru Hektoroviću, budući nas pohodio u Dubrovnik i poslije vrativši se on u Hvar, piše mu se na 18. dečembra 1557. (Nalješković 2005: 301-302).

63 Pelegrin Sabu Mišetiću (Frangeš 19682:134-141).

64 Odgovor Saba Mišetića Piligrinu (idem: 340-349).

65 Svake velike časti dostojnomu Nikoli Stjepka Nalješkovića Hortenzij Bartučević Hvaranin piše (Prosperov Novak 1978: 44-52).

66 Gospodinu Hortenziju Brtučeviću, vlastelinu hvarskomu, Nikola Stjepka Nalješkovića Dubrovčanin umiljeno preporučajući se piše (Nalješković 2005: 307).

67 Zvrsno poštovanu i svake časti dostojnomu gospodinu Nikoli Nalješkoviću Dubrovčaninu Hortenzij Bartučević Hvaranin piše (Prosperov Novak, 1978: 44-52).

68 Gospodinu Dživanu Parožiću, vlasteličiću hvarskomu, u pohvalu njegove Vlahinje Nikola Stjepka Nalješkovića Dubrovčanin piše (Nalješković 2005: 306). 
41. Ivan Parožić > Nikoli Nalješkoviću (oko 1560.), Hvar > Dubrovnik ${ }^{69}$

42. Šime Budinić > Mikši Pelegrinoviću (između 1559. i 1561.), Zadar $>$ Zadar $^{70}$

43. Petar Hektorović > Vicencu Vanettiju (1561.), Stari Grad > Hvar, tal. ${ }^{71}$

44. Nikola Nalješković > Petru Hektoroviću (poslije 1560.), Dubrovnik > Stari Grad ${ }^{72}$

45. Nikola Nalješković > Ivanu Vidaliju (1564.), Dubrovnik > Korčula ${ }^{73}$

46. Hortenzij Bartučević > Brni Karnarutiću (oko 1570.), Hvar > Zadar $^{74}$

47. Šime Budinić $>\left(1582\right.$.) Zadar $>^{75}$

\section{DRUGO HVARSKO INTELEKTUALNO POLJE}

Drugo hvarsko intelektualno polje formira se sredinom XVI. stoljeća. Možemo reći da je njegova središnja ličnost Petar Hektorović, koji svojom poslanicom upućenom Vetranoviću 1539. godine otvara „komunikacijski kanal” prema Dubrovniku. Vrlo brzo, već 1540 . godine, svojom prvom od šest poslanica upućenih Hektoroviću, u njega se inkorporira Nikola Nalješković kao najplodniji „poslaničar” i „skupljač prijatelja" (tako bismo rekli kada bismo rabili suvremene izraze za internetske komunikacijske mreže) u tome stoljeću. Hektorović i Nalješković su „kičma” toga polja. Hektorović je odmah na početku od Vetranovića i Nalješkovića apostrofiran kao najslavniji pisac ne samo Hvara, nego i ostalih država našega jezika (poslanica br. 20) jer je on proslavi slovinski jezik vas (posl. br. 19). Na kojim djelima se zasniva ta Hekto-

69 Svake hvale dostojnomu gospodinu Nikoli gospodina Stjepka Nalješkovića Dubrovčanina Dživan Parožić Hvaranin piše (Frangeš 1968² : 459-460).

70 Tu pohvalnicu Pelegrinovićevoj Jeđupki navodi Prosperov Novak (1997: 638).

71 Izvrsnomu umjetnosti i medicine doktoru g. Vincencu Vanettiju moje najdublje poštovanje (Frangeš 1968': 257-261).

72 Gospodinu Petru Hektoroviću, vlastelinu hvarskomu, Nikola Stjepka Nalješkovića piše vrhu njih starosti (Nalješković 2005: 318-320).

73 Gospodinu Ivanu Vidali, vlastelinu krkarskomu, Nikola Stjepka Nalješkovića Dubrovčanin piše na 16. novembra 1564. (Nalješković 2005: 310-311).

74 Plemenitu i svake izvrsne časti dostojnome gospodinu Bernardinu Karnarutiću, vlastelinu zadarskomu u pohvali Tižbe i Šegeta Hortenzij Bartučević Hvaranin piše (Prosperov Novak 1978: 44-52).

75 „Kratki stihovani zapis” (Prosperov Novak 1997: 638-639). 
rovićeva slava početkom četrdesetih godina XVI. stoljeća? Ribanje još nije napisao, a prijevod Ovidija mu sigurno nije mogao priskrbiti takvu čast. Vetranović samo navodi pjesni medene (posl. br. 19), a Nalješković navodi pjesni ljuvezne i mužu Taliju (posl. br. 20) koja mu je svila lovorov vijenac na glavi, dakle danas nepoznate Hektorovićeve ljubavne pjesme i njegova dramska djela. Hektorović ima poseban odnos bliskosti s malo starijim Vetranovićem, koji mu čak oleandre i čemprese šalje za njegov Tvrdalj, a mlađega Nalješkovića cijeni zbog novog puta, novog druma (posl. br. 21) kojim Nalješković korača u književnost. Nekakav nejasan odnos poštovanja ima i prema Dimitroviću (posl. br. 21), čije su ga kratke refleksivne pjesme možda mogle inspirirati za sentence njegovih ribara u Ribanju. Hektorović je i ona spona koja mlađu generaciju hvarskih pjesnika (Hortenzija Bartučevića, prije svega) povezuje s Nalješkovićem (posl. br. 37 i 38).

Od prve generacije hvarskih renesansnih književnika, rođene prije 1500 . godine, sada, sredinom stoljeća, aktivni su samo, barem po poslanicama, Hektorović i Bartučević. Bartučeviću je dodatnu slavu dalo papinsko odlikovanje viteza zlatne ostruge 1547. godine. Hanibalu Luciću kao centralnoj ličnosti prvoga hvarskog intelektualnog polja, onog koje se formira u drugom desetljeću XVI. stoljeća, sada se gubi trag. Spominje ga jedino Kotoranin Ludovik Paskalić (i neki drugi kotorski pjesnici, o čemu će biti riječi u Dodatku), kasni petrarkist kojemu su Lucićevi ljubavni stihovi iz mladosti možda bili uzor za vlastito pjevanje. Zaista se čini da je Hanibal Lucić prestao skladati (na hrvatskom jeziku) s izlaskom iz svoje mladosti. Njegova djela koja je objavio sin mu Antun 1556. godine (a sigurno su to bila sva koja je Hanibal ostavio iza sebe) su mladalački opus. Za razliku od njega, Hektorović je u dubokoj starosti, 1568. godine, odlučio objaviti samo svoj zreli, a mogli bismo reći i starački opus. Izdavač je u oba slučaja bio isti - Antun Lucić i žena mu Julija, nasljednici Lucića i Hektorovića. Zbog takve razlike u dostupnim nam opusima (mladalački Lucićev i starački Hektorovićev) teško ih je uopće uspoređivati. Da su nam dostupne one Hektorovićeve pjesni medene i pjesni ljuvezne o kojima govore Vetranović i Nalješković, sigurno Hektorović ne bi bio samo razboriti, mudri, kriposni pjesnik. Ali, očito, on je želio, izborom svojih objavljenih djela, ostaviti nam sasvim određenu sliku o sebi.

Hektorović je svojim odlaskom u Dubrovnik 1557. godine s tek napisanim Ribanjem posvjedočio o još jednoj bitnoj karakteristici ponašanja stvaratelja u intelektualnom polju, karakteristici o kojoj govori 
Bourdieu - potrebi stvaratelja za javnim smislom djela. On u Dubrovniku, časti našega jezika, književnoj prijestolnici sredine XVI. stoljeća, traži priznanje za svoje novo djelo, želi čuti odjek djela među onima u čiji ukus najviše vjeruje. Tek nakon toga (i legitimnosti koju mu daje posveta Bartučeviću) šalje novo djelo dalje, u Zadar u kojem od 1549. godine živi Pelegrinović. Mlađem Pelegrinoviću ima potrebu u popratnom pismu objasniti i svoj književni postupak i poslati mu notni zapis. Pelegrinović mu treba kao most prema novoj književnoj publici, onim mlađim zadarskim književnicima o kojima kao sudionicima hvarskog intelektualnog polja svjedoče preživjele poslanice - Brni Karnarutiću i Šimu Budiniću. Pelegrinović je hvarska veza u Zadru. Njemu se obraća i mlađi dubrovački pjesnik Sabo Bobaljević (posl. br. 36), šaljući preko njega pozdrave Držiću, koji je tada, vjerojatno nakratko, u Zadru. To je i jedina potvrda o nekom „perifernom” sudjelovanju Marina Držića u tom našem polju (osim ako ne uzmemo u obzir iskreno prijateljstvo Vetranovića i Držića, pa posredno, preko Vetranovića, kao osvjedočenoga hvarskog „zagovaratelja”, ne „nategnemo” neki mogući dodir).

Najmlađi hvarski književnik toga polja je Ivan Parožić. Rođen 1537. godine, treća je generacija hvarskih književnika. Prva su oni rođeni do 1500. godine: Paladinić, Lucić, Hektorović, Bartučević i nepoznati Katerin; Pelegrinović bi rođenjem oko 1500 . godine bio već druga, ali je književno aktivan vrlo rano, pa ga Pribojević uvrštava u slavni hvarski četverac. Drugu generaciju zastupa Hortenzije Bartučević, rođen 1516. god. Preživjele poslanice govore nam da su ipak svi oni „zamukli” oko 1570. godine. Hektorović umire 1572., a godinu ranije, 1571., Hvar je opustošila turska flota u predvečerje Lepantske bitke. Posljednja su desetljeća XVI. stoljeća vrijeme hvarske dekadencije. Martin Benetović na samom kraju stoljeća slučaj je za sebe. Pučanin, svestrani artist (uz pisanje komedija, on je i slikar i orguljaš), usamljeni je umjetnik na otoku, čije su veze s drugim književnicima nepoznate, a moguće je da nisu ni postojale. Svijet se je u međuvremenu stubokom promijenio. Protureformacija je zavladala „,istočnojadranskim društvenim prostorom", a ni Hvar više nije živahna luka s početka stoljeća. Benetović se sigurno ne može osjećati kao Lucić osamdeset godina prije mornarom na putu. Benetović nije bogati plemić, on je zastupnik pučana i artist koji živi od svog umjetničkog rada. Drugo hvarsko intelektualno polje, jednako elitističko kao i prvo, nestalo je najkasnije sedamdesetih godina XVI. stoljeća. Kraj toga stoljeća početak je provincijalizacije hvarske intelektualne scene, „duge mračne intelektualne noći”, koja će trajati skoro do kraja postojanja Mletačke Republike (v. karte 4 i 5). 
Prije samoga zaključka o hvarskim intelektualnim poljima još kratke napomene:

1. Preko Nalješkovića dio toga polja bila su i dvojica obrazovanih Korčulana, Ivan Vidali i Antun Rozanović. Splita više nema u tome polju, a osovina mu je linija Hvar - Dubrovnik. Korčula je usputna stanica na toj liniji. Da nije Pelegrinović kraj svoga života proživio u Zadru, ni Zadar ne bi ušao u „interesnu sferu” Hvarana.

2. Gotovo programatski Hektorovićevi stihovi iz poslanice Nalješkoviću 1541. godine Zaman je muže zvat i boge poganske, / Potrebno je iskat načine karstjanske mogli bi biti ključ za novi senzibilitet koji se stvara oko sredine XVI. stoljeća. Hektorovićeva poslanica jedinoj ženi toga polja, Graciozi Lovrinčevoj, upućena je pobožnoj časnoj sestri, a ne lijepoj Trogiranki, kao u prvom polju. To se polje formira u vrijeme Tridentskoga koncila, vrijeme protuudara Katoličke crkve na reformske pokrete, vrijeme obnove tradicionalne pobožnosti. Ali, to već prelazi okvire ovoga rada i opet je samo napomena za moguće nove interpretacije književnosti Hvara sredinom slavnoga renesansnog stoljeća.

\section{ZAKLJUČAK}

Korpus nama dostupnih „komunikacijskih tekstova” u području hvarskih intelektualnih polja obuhvaća 47 tekstova. Najviše ih je na hrvatskom jeziku - 37, osam tekstova pisano je latinskim, a dva talijanskim jezikom. Od hrvatskih tekstova 29 je „klasičnih” poslanica, jedna nadgrobnica, dvije su poslanice upućene kolektivnom adresatu (Lucićeva Dubrovniku i Vetranovićeva hvarskoj vlasteli), a jedna je pjesma Šime Budinića. Ona nije poslanica, ali je svojevrsni zaključni tekst XVI. stoljeća kojim se uspostavlja hijerarhijska ljestvica dalmatinskih književnika. Prozom su napisana četiri teksta, od kojih su tri svojevrsne posvete onima koji književno djelo trebaju izvesti $n a$ dvor, a jedan je „klasična” poslanica (Hektorović Pelegrinoviću). Latinskih tekstova je osam, od čega su sedam elegije ili pjesme poslanice, a jedna je prozna posveta (Pribojević Vitaljiću).

Samo su dva talijanska teksta: jedna pjesma poslanica (Paskalić Luciću) i jedno prozno pismo (Hektorović Vanettiju). Sve proučavane tekstove pokušalo se datirati. Stvorena kronologija nije apsolutna, ali je vrlo vjerojatna. Iz te kronologije proizašla su dva hvarska intelektualna polja. 
Prvo obuhvaća razdoblje između 1496. (Božićević Paladiniću) i 1528. (Hektorović Pelegrinoviću), ali smo kao simbolični kraj toga polja uzeli 1532. godinu, kada je tiskan Pribojevićev govor. Ondje je 18 komunikacijskih tekstova. Drugo polje obuhvaća razdoblje od 1539. (razmjena poslanica Hektorović Vetranović) do oko 1570. godine (Hortenzije Bartučević Karnarutiću). U tom polju je 29 tekstova.

U prvom hvarskom intelektualnom polju hvarski književnici komuniciraju jedino sa splitskim književnicima, s „Marulićevom ekipom”. Centralna ličnost $s$ hvarske strane je Hanibal Lucić, a sa splitske Jeronim Martinčić. Njihovo prijateljstvo je „kičma” polja. U tom razdoblju nastala su najvažnija književna djela Hanibala Lucića - ljubavni kanconijer i Robinja, te Lucićev prijevod Ovidija. Od Petra Hektorovića ostao je (iz toga razdoblja) prijevod Ovidija, a od Mikše Pelegrinovića Jeđupka. Objavljena je i prva, možda i najvažnija, hvarska knjiga - Pribojevićev govor O podrijetlu i slavi Slavena. Drugo hvarsko intelektualno polje koje živi sredinom XVI. stoljeća obilježeno je osovinom Hvar - Dubrovnik, a „kičmu” mu čini prijateljski odnos Hektorović - Nalješković. Prema Zadru se Hvar okreće nakon 1549. godine, kada Pelegrinović postaje zadarski sudac. Šezdesetih godina XVI. stoljeća prekida se veza s Dubrovnikom, a nastavlja još kratko vrijeme sa Zadrom. Sedamdesetih godina toga stoljeća Hvar intelektualno, stvaralački zamire. Na kraju stoljeća u Hvaru živi jedino usamljeni artist, pučanin Martin Benetović, a između Hvara i Visa kreće se posljednji hvarski plemić-književnik, manirist Marin Gazarović. U tom razdoblju nastalo je Hektorovićevo Ribanje, zapravo gotovo cijeli danas poznati Hektorovićev opus. Ivan Parožić napisao je Vlahinju, danas izgubljenu. Mikša Pelegrinović je 1556. uredio svoju Jeđupku za objavljivanje i posvetio je dubrovačkoj omladini, ali je ipak ostala neobjavljena.

Svi sudionici obaju polja s hvarske strane su plemići, i to oni iz najbogatijih vlastelinskih obitelji. Tako je i sa Splićanima, Korčulanima, Zadranima. Jedino su tri dubrovačka književnika pučani, kao i Zadranin Budinić. Društveni odnosi na Hvaru (krvavi pučki ustanak, neprekidni društveni sukobi) ne vide se u poslanicama, ${ }^{76}$ a nekakva razlika u stavu prema „aristokraciji” između Lucića i Hektorovića

76 Izuzetak je nekoliko tendenciozno tumačenih Lucićevih stihova o mnoštvu koje dil razbora ne ima, što bi današnji teoretičari opravdano nazvali samo „psihologijom mase“. $\mathrm{Na}$ istom tragu je i Hektorovićeva rečenica iz pisma Vincencu Vanettiju: „[...] jerbo ne dolikuje jednoj osobi toga staleža [...] nasljedovati neuku svjetinu koja ne znade nikad izabrati ni učiniti stvar što bi bila dobra [...]." (Frangeš 1968': 259). 
tumačena na temelju Lucićeve pohvale dubrovačkoj vlasteli, postaje izlišna kada se čita Hektorovićeva pohvala istoj vlasteli u poslanici Pelegrinoviću (poslanica 33). Kada se pročita Vetranovićeva adoracija hvarske vlastele (poslanica 28), postaje jasno da jedini društveni prostor Hvara koji se ocrtava u tim poljima jeste onaj elitni vlastelinski. Od zbiljskoga prostora Hvara jedino se, opet u Vetranovića (poslanica 19), pojavljuje Tvrdalj u Starome Gradu, kao ostvareni humanistički ideal prostora ljepote i kontemplacije, zaklonište od „kuge, gladi i rata”, teške stvarnosti dalmatinskoga XVI. stoljeća.

\section{DODATAK: SLUČAJ LUCIĆ > TALIJANSKO INTELEKTUALNO POLJE (?)}

Novootkrivena, dosad nepoznata knjiga talijanskih stihova Hanibala Lucića Sonetti di messer Anibal Lucio Lesignano, scritti a diversi, tiskana 1556. godine u Veneciji, čija je čak dva potpuno očuvana primjerka Ivan Lupić pronašao na Sveučilištu Yale (Knjižnica rukopisa i rijetkih knjiga Beinecke) i u Sveučilišnoj knjižnici u Paviji, ${ }^{77}$ a promptno ju na hrvatski jezik preveo Tonko Maroević, ${ }^{78}$ prevodilac šest jedinih do toga pronalaska poznatih talijanskih Lucićevih soneta, ${ }^{79}$ otvara neka nova pitanja, pitanja koja u ovom dodatku želimo barem naznačiti.

\section{Hanibal Lucić kao politički pjesnik}

Od 25 Lucićevih soneta 12 ih je upućeno mletačkim upraviteljima na Hvaru i u Dalmaciji. Možda je i trinaesti naslovljen Mom jedinom zaštitniku g. Mateju Fideleu, osobi koju nismo uspjeli detektirati, upućen također nekom mletačkom ugledniku. Dakle više od polovice soneta su svojevrsni politički soneti, kako ih imenuje Lupić..$^{80} \mathrm{U}$ dva soneta Lucić govori u ime kolektiva - Hvara (sonet 2. Matheu Maripetru) i Dalmacije (sonet 4. Marcantoniju da Mulla), a zapravo hvarskog i dalmatinskog plemstva. U 21. sonetu naslovljenom Gospodinu Aleksandru Bizantiju to i u naslovu ističe: u ime hvarskih plemića. Lupić dobro primjećuje da Hanibal u svim tim sonetima nastupa kao službeni pjesnik Hvara, da su oni možda nastali kao dio javnoga poli-

77 Lupić 2018: 5-41.

78 Maroević 2018: 367-385.

79 Maroević 1987: 231-248.

80 Idem: 18. 
tičkog rituala, napisani možda po narudžbi kod imenovanja novih dužnosnika, što je česta praksa širom novovjekovne Europe, te da su u njima izraženi osjećaji pripadanja službenoj ideologiji i klasi. ${ }^{81}$

Uloga Hanibala Lucića kao političkoga pjesnika, službenoga pjesnika hvarskoga plemstva koja se ovdje jasno očitava, snažno naglašava njegov ,aristokratski stav” o kojem su često govorili stariji istraživači (v. kartu 6).

\section{Lucićevo talijansko intelektualno polje}

Već smo prije, govoreći o Prvom hvarskom intelektualnom polju, istaknuli da je cjelokupni Lucićev hrvatski opus nastao u mladenačkom periodu njegova života (osim možda posljednje poslanice Jerolimu Martinčiću, kojoj je priložena pjesma Od Božićne noći, kratke nadgrobnice istome Martinčiću i pjesme U pohvalu grada Dubrovnika). Također smo uočili da u vrijeme Drugoga hvarskog intelektualnog polja Lucić nigdje nije vidljiv. Na osnovi sigurnih datacija nekih soneta upućenih mletačkim uglednicima (po godinama imenovanja ili djelovanja tih dužnosnika u Dalmaciji) i po dataciji soneta razmijenjenih s Ludovikom Paskalićem (koji se u Kotor vraća 1538. godine, svoju knjigu talijanskih stihova objavljuje 1549., a umire 1551.) možemo reći da su Sonetti Hanibala Lucića nastali od sredine tridesetih godina XVI. stoljeća pa do pred njegovu smrt (sonet naslovljen Kristoforu da Canale). Čini se sada gotovo sigurnim da Hanibal Lucić u zrelim i starijim godinama napušta pisanje na hrvatskom jeziku i piše isključivo na talijanskom. Kada je tako, onda je sasvim logično da se okreće kotorskom krugu pjesnika koji pišu jedino na talijanskom i latinskom jeziku. Drugi dio njegovih Sonetta gotovo je u potpunosti upućen kotorskim pjesnicima.

U vrijeme kada u Dubrovniku cvate književnost na hrvatskom jeziku, a Hektorović i drugi hvarski pjesnici intenzivno razmjenjuju hrvatske poslanice, u susjednom Kotoru djeluju domaći pjesnici, zakašnjeli petrarkisti, koji pišu isključivo na talijanskom (i latinskom) jeziku. Tu neobičnu situaciju Slobodan Prosperov Novak pokušava objasniti „stanovitom obranom od divlje okoline ali i znakom odano-

81 Ibidem. 
sti venecijanskim gospodarima i njihovom talijanskom idiomu”. ${ }^{82}$

Hanibal Lucić u 14. sonetu naslovljenom Ludoviku Paskaliću, nabrajajući u njemu čuvene kotorske porodice („grupa zgodna” Buće, Pellegrini, Bizanti i Pontani), obraća im se kao središtu i najvažnijem mjestu „našeg podneblja” gdje se stvara književnost. ${ }^{83}$

Ludoviku Paskaliću je Hanibal Lucić namijenio čak četiri soneta, a uvrstio je u svoju knjigu i sonet koji Paskalić šalje njemu. Taj sonet u malo modificiranom obliku objavio je i Paskalić u svojoj knjizi Rime volgari iz 1549. godine. Njihovo međusobno uvažavanje proizlazi vjerojatno iz srodnosti njihovih poetika. ${ }^{84}$

Jedan Lucićev sonet (19) naslovljen je na Jurja Bizantija (Kotor, 1490. - oko 1560.), najstarijem kotorskom petrarkistu, koji je prvi od naših pisaca objavio knjigu talijanskih stihova, Rime amorose, 1532. godine u Veneciji. Njega ističe među „muževima glasovitim zbog svog književnog rada" i Vinko Pribojević. ${ }^{85}$ Čini se da je Juraj Bizanti onaj neimenovani tajnik (cancelier) Hvara o kojem s velikim poštovanjem pišu Hanibal Lucić u sonetu 21 (Gospodinu Aleksandru Bizantiju u ime hvarskih plemića) ${ }^{86}$ i nepoznati nam kotorski pjesnik Aleksandar Bizanti u sonetu 21a (Hvarskoj vlasteli Aleksandar Bizanti) ${ }^{87}$. Naime, tako proizlazi iz podatka o imenovanju Jurja Bizantija kancelarom Hvara, podatku koji navode Franić Tomić i Prosperov

82 „U Kotoru nije se narodni jezik niti u lijepoj književnosti niti u kronikama dugo upotrebljavao. Prvi književni tekstovi na narodnom jeziku datirani su u ovom najjužnijem dijelu Dalmacije tek početkom XVII. stoljeća što se može tumačiti stanovitom obranom od divlje okoline ali i znakom odanosti venecijanskim gospodarima i njihovom talijanskom idiomu." (Franić Tomić - Prosperov Novak 2015: 13).

83 „U podneblju našemu zalud tražim, / Paskaliću, grad što toliko stvara / Ko Kotor i što čašću se osnaži / Djelima skladom od devet sestara" (Maroević 2018: 374).

84 „U vrijeme kad je Paskalić pisao pohvalnicu Luciću, Hvaraninova jedina knjiga još i nije bila tiskana, ali ju je Kotoranin očito poznavao, pa je s razlogom osjetio srodnost svojih talijanskih pjesama s Lucićevim hrvatskim kanconijerom, u kojemu je također presudan utjecaj Pietra Bemba i njegove reforme." (Franić Tomić - Prosperov Novak 2015: 27).

85 Pribojević 1997: 73-74.

86 „Da služba mu u upravi nam grada / Ko plemiću je skoro neprilična.” (Maroević 2018. 378).

87 „Možete zbilja dičit se i hvalit, / Plemenita vlastelo grada Hvara / Što dostojnog ste tajnika, pisara, / Na svijetu danas rijetkog, izabrali” (ibidem). 
Novak, ne donoseći vrelo odakle ga crpe. ${ }^{88}$ Po tome bi ti soneti bili napisani oko 1535. godine.

Pjesniku Vicku Bući posvetio je Lucić dva soneta (23 i 24). O Vicku Bući danas malo znamo. ${ }^{89}$ Taj Vicko Buća izgleda da nije onaj učeni dominikanac kojega spominje Pribojević s bratom mu Dominikom, ${ }^{90}$ kako misle Franić Tomić i Prosperov Novak, ${ }^{91}$ jer Miljenko Foretić u Hrvatskom biografskom leksikonu navodi da je on brat pjesnika Frana, a da ga greškom u starijoj literaturi poistovjećuju s istoimenim dominikancem..$^{92}$

Sonet Izvrsnomu gospodinu Marinu Grubonji, kotorskom plemiću Lucić je namijenio danas potpuno nepoznatom kotorskom pjesniku. Nepoznata je i jedina žena, pjesnikinja Orsola Tetrica (Desetoj muzi gospođi Orsoli Tetrica), koju Lucić u sonetu uspoređuje sa Sapho i Kasandrom, a za koju Lupić misli da bi mogla biti Uršula Detrico iz Zadra. $^{93}$

Posljednji sonet u zbirci namijenjen je Franu Božićeviću Natalisu (G. Franji Natali plemiću splitskom), kojemu je Hanibal Lucić uputio i jednu hrvatsku poslanicu. U njoj Lucić ističe kako je obojici Fortuna sklona (možda aluzija na Božićevićevo preživljavanje strašne epidemije kuge 1526. - 1527. u Splitu) i kako može biti ponosan na svoje

88 „Bio je državni činovnik u Kotoru gdje ga izvori 1531. bilježe na sudačkoj dužnosti. Kasnije je bio kancelar na otoku Hvaru to jest cancellarius Lesinae, a pokušao se upravo za vrijeme toga hvarskog boravka u ožujku 1536. natjecati za mjesto kancelara u kriminalističkoj službi u dalmatinskoj prijestolnici Zadru ali nije bio na tu visoku funkciju izabran. Tada se vratio u Kotor [...]" (Franić Tomić - Prosperov Novak 2015: 39).

89 Franić Tomić i Prosperov Novak navode samo: „epistole Vicka Buće objavljene su u knjigama Dubrovčanina Klimenta Ranjine (Araneus): Quodlibet declamatorium, tiskanoj u Veneciji 1541. i u njegovu djelu Expositio...super epistulam Pauli ad Romanos per modum lecturae, također objavljenom u Veneciji 1547." (Franić Tomić - Prosperov Novak 2015: 23).

90 „Kotorani Vinko i Dominik Buća, dominikanci, koji su svojim djelima rasvijetlili brojne tajne katoličke vjere" (Pribojević 1997: 73).

91 Franić Tomić - Prosperov Novak 2015: 22.

92 HBL 1989: 415-416.

93 Ivan Lupić također pretpostavlja da bi ova Cassandra mogla biti Cassandra Fedele, učena i slavljena venecijanska pjesnikinja, kojoj jednu pjesmu na latinskom jeziku posvećuje Hvaranin Pavle Paladinić u svojem rukopisnom kanconijeru iz 1496. godine, što otvara pitanje je li o njoj Lucić znao iz toga Paladinićevog rukopisa ili je bio neposredno upoznat s njenim djelom (Lupić 2018: 20). 
već odrasle sinove koji su mudrosti svih prepuni i vrlina. ${ }^{94}$ Po tome bi ga mogli datirati u tridesete godine XVI. stoljeća.

Tim pjesnicima definirano je Lucićevo talijansko intelektualno polje. Što je moglo nagnati Hanibala Lucića da u posljednjim dekadama života odustane od pisanja na hrvatskom jeziku i da se isključivo posveti sonetima i okrene kotorskim petrarkistima koji pišu samo na talijanskom jeziku? (V. kartu 7.)

\section{Sonet kao pitanje identiteta}

Razmatrajući problem soneta u starijoj hrvatskoj književnosti Svetozar Petrović zaključit će da su „naši pjesnici bili privrženi tradicionalnim metričkim oblicima zato što su se ovi osjećali kao domaći, slovinski, dok je sonet bio smatran tuđom formom koja ne pristaje našem pjesništvu. [...] Po srijedi [je] bio svojevrstan - mogli bismo uvjetno reći - nacionalni izbor, izbor kojim je odlučila povezanost s vlastitom sredinom (a ne nipošto izbor nametnut karakterom jezika samog po sebi, ili stupnjem versifikatorske vještine ili umjetničke zrelosti naših pjesnika, ili metričkim nasljeđem koje bi se shvatilo samo kao zbir usvojenih metričkih konvencija, ili, najzad, vrstom pjesništva koje su stvarali)". ${ }^{55}$ Drugim riječima, prihvaćanje dvostrukorimovanoga dvanaesterca kao temeljnoga stiha za naše starije pjesnike, kao i neprihvaćanje soneta na hrvatskom jeziku za naše petrarkiste, bio je svojevrsni nacionalni izbor. Ti prvi naši pjesnici u Mletačkoj Dalmaciji i Dubrovniku živjeli su u relativno izoliranim, međusobno udaljenim gradskim središtima, izloženi utjecajima talijanske prekojadranske kulture, ali i vlastitoga zaleđa. Upravo „veza sa zaleđem znači identificiranje s maticom vlastitog jezika, identificiranje kakvo je zadato biti pjesništva više negoli uvjetima njegova života". ${ }^{96}$ Metametričke osobine dvostrukorimovanoga dvanaesterca, a ne talijanskoga jedanaesterca (endecasillaba, temeljnoga stiha talijanskoga soneta) ta su „veza sa zaleđem”, pa je prihvaćanje dvanaesterca svojevrsna „legitimacija pripadnosti odvojenim pjesničkim tradicijama”.97

Kako su talijanski jezik i talijanska poezija bili vrlo dobro poznati našim renesansnim pjesnicima u dalmatinskim središtima, a većina

94 Maroević 2018: 381.

95 Petrović 1968: 91.

96 Idem: 98.

97 Mrdeža Antonina 2009: 41. 
njih je i pisala na oba jezika i još k tome na latinskom, odabir metričkog oblika bio je, čini se, čin identitetskog odabira. „[...] sonet je za njih bio potpuno vezan za talijansko pjesništvo jedne vrste i pisati sonet značilo je pisati talijanskim jezikom". ${ }^{98}$

Nije poznat nijedan sonet na hrvatskom jeziku u hvarskoj književnosti XVI. stoljeća. Za Hektorovića izričito znamo, po njegovim vlastitim riječima u pismu Vicenzu Vanettiju u kojemu donosi, recimo tako, recenziju jednoga Vanettijevog soneta na talijanskom, da se nije nikada bavio pisanjem soneta: „[...] prije svega zahvaljujem vašem gospodstvu koje me iznad svakog očekivanja (ovu mi oprostite) smatra dostojnim tolike časti da ja imam suditi o vašemu sonetu, najpače znajući i spoznavajući da ja nisam od te struke". ${ }^{99}$

Ako prihvatimo Petrovićevu tezu da je odabir metričkog oblika bilo prije svega identitetsko pitanje, onda je Petar Hektorović (ali ne samo po tome nego i po cjelokupnom djelu, a po Ribanju svakako, o čemu će još biti riječi) duboko povezan sa zaleđem, odnosno s „maticom vlastitoga jezika”.

Znači li to također da Hanibal Lucić u starijim godinama svoga života prekida tu vezu?

Podsjetimo se da je Zan Battista Giustinian, opisujući grad Hvar 1556. godine, za njega rekao da je, pored Zadra, najtalijanskiji u Dalmaciji. Gotovo svi muškarci i žene nose talijansku odjeću, a svi muškarci tečno govore lingua franca ${ }^{100}$ (zapravo mletački kolonijalni jezik, venecijanski talijanski idiom). Slika o Hvaranima koji teže imitirati Talijane, čiji se slavenski identitet koleba u dodiru s brojnim strancima koji posjećuju njihovu luku, jako je različita od one koja se pojavljuje u hvarskoj književnosti. Nije isključeno da sredinom stoljeća postoje i određene razlike između samoga grada Hvara i središnjega dijela otoka u kojemu živi Hektorović. Nameće li nam se zaključak da se i Lucićev slavenski identitet pri kraju njegovoga života koleba?

98 Petrović 1968: 97.

99 Frangeš 1968': 260.

100 Šimunković 2011: 66. 


\section{LITERATURA}

\section{BOURDIEU 1970}

Pierre Bourdieu, „Intelektualno polje i stvaralačka zamisao”, Kultura, 10, Beograd 1970, 74-107.

\section{BUDAK 1997}

Neven Budak, „Urban elites in Dalmatia in the fourteenth and fifteenth centuries", Atti e memorie della Società dalmata di storia patria XXVI, Venezia 1997, 183-199.

\section{FALIŠEVAC 2008}

Dunja Fališevac, „Renesansna poslanica kao prostor poetičko-estetičkih iskaza”, Colloquia Maruliana, 17, Split 2008, 7-25.

FORETIĆ 1970

Vinko Foretić, „Hektorovićevo doba na relaciji Hvar - Korčula Dubrovnik", Zbornik radova o Petru Hektoroviću, Posebno izdanje časopisa Kritika, sv. 6, Zagreb 1970, 131-145.

\section{FRANGEŠ $1968^{1}$}

Ivo Frangeš (ur.), Hanibal Lucić / Petar Hektorović, Pet stoljeća hrvatske književnosti, knjiga 7, Zagreb 1968.

\section{FRANGEŠ $1968^{2}$}

Ivo Frangeš (ur.), Zbornik stihova XV. i XVI. stoljeća, Pet stoljeća hrvatske književnosti, knjiga 5, Zagreb 1968.

FRANIĆ TOMIĆ - PROSPEROV NOVAK 2015

Viktorija Franić Tomić - Slobodan Prosperov Novak, Književnost ranog novovjekovlja u Boki kotorskoj, Zagreb 2015.

GORTAN - VRATOVIĆ 1969

Veljko Gortan i Vladimir Vratović (prir.), Hrvatski latinisti, Pet stoljeća hrvatske književnosti, knjiga 2/l, Zagreb 1969.

\section{GRACIOTTI 2005}

Sante Graciotti, Il petrarchista dalmata Paolo Paladini e il suo canzoniere (1496), Roma 2005.

\section{GRACIOTTI 2006}

Sante Graciotti, „Jedan gotovo nepoznat dalmatinski petrarkist: Paolo Paladini”, Petrarca i petrarkizam u hrvatskoj književnosti, Split 2006, 57-68.

HBL 1989

N. Kolumbić et al. (ur.), Hrvatski biografski leksikon, Zagreb 1989. 
JOVANOVIĆ 2006

Neven Jovanović, „Prolegomena za Marulićevu splitsku ekipu”, Colloquia Maruliana, 15, Split 2006, 10-25.

LUPIĆ 2018

Ivan Lupić: ,Italian poetry in early modern Dalmatia: The strange case of Hanibal Lucić (1485-1553)", Colloquia Maruliana, 27, Split 2018, 5-41.

MARKOVIĆ 1958

Miroslav Marković (ur.), Pesme Franja Božićevića Natalisa, Beograd 1958.

MAROEVIĆ 1987

Tonko Maroević, „Hanibal Lucić, pjesnik „mornarom na putu” (uz prepjev njegovih talijanskih soneta)", u: Dani hvarskog kazališta, Hanibal Lucić, knjiga XIII, Split 1987, 231-248.

MAROEVIĆ 2018

Tonko Maroević, „Hanibal Lucić: Talijanske pjesme”, Forum, 4-6, Zagreb 2018, 367-385.

\section{MRDEŽA ANTONINA 2009}

Divna Mrdeža Antonina, „Stih u pjesništvu Dinka Ranjine u kontekstu metrike petrarkističkog pjesništva", Umjetnost riječi, LIII (1-2), Zagreb 2009, 29-46.

NALJEŠKOVIĆ 2005

Nikola Nalješković, Književna djela, Zagreb 2005.

NOVAKOVIĆ 2001

Darko Novaković, „Dvije nepoznate latinske elegije Jeronima Bartučevića”, Vijenac, 188, Zagreb 2001, 6.

PETRIĆ 1998

Nikša Petrić, „De Caterino poeta Pharensi, Povodom Marulićevih pjesama Katerinu i Hanibalu", Colloquia Maruliana, VII, Split 1998, 215-224.

PETROVIĆ 1968

Svetozar Petrović, „Problem soneta u starijoj hrvatskoj književnosti”, Rad JAZU, 350, Zagreb 1968.

PRIBOJEVIĆ 1997

Vinko Pribojević, O podrijetlu i slavi Slavena, Zagreb 1997.

PROSPEROV NOVAK 1978

Slobodan Prosperov Novak, „Hortenzij Bartučević (1516-1578)”, Prilozi povijesti otoka Hvara, 5, Hvar 1978, 44-52. 
PROSPEROV NOVAK 1997

Slobodan Prosperov Novak, Povijest hrvatske književnosti, II. knjiga, Zagreb 1997.

\section{RAUKAR 1997}

Tomislav Raukar, Hrvatsko srednjovjekovlje, Zagreb 1997.

\section{REŠETAR 1901}

Milan Rešetar, „Ein Sendschreiben Vetranovičs an Hektorović (Plemenitomu i vrijednomu gospodinu Petru Ektoroviću vlastelinu hvarskomu s velikijem priklonstvom odgovor umiljen D. Mavra Vetrani)", Archiv für slavische Philologie, XXIII, Berlin 1901, 206-215 (tekst pjesme 208-215).

\section{STIPČEVIĆ 2012}

Ennio Stipčević, „Kotoranin Paskalić i trojica Talijana”, Vijenac, 490-491, Zagreb 2012, 18.

ŠIMUNKOVIĆ 2011

Ljerka Šimunković, Dalmacija godine gospodnje 1553., Putopis po Istri, Dalmaciji i Mletačkoj Albaniji 1553. godine, Zapisao Zan Battista Giustinian, Split 2011.

VONČINA 1986

Josip Vončina (prir.), Djela Petra Hektorovića, Zagreb 1986.

\section{Internet:}

Mavro Vetranović, Vlasteostvu hvarskomu

https://hr.wikisource.org/w/indeks.php?title=Vlasteostvu_hvarskomu\&oldid=50803 [pristupljeno 21. 12. 2016] 


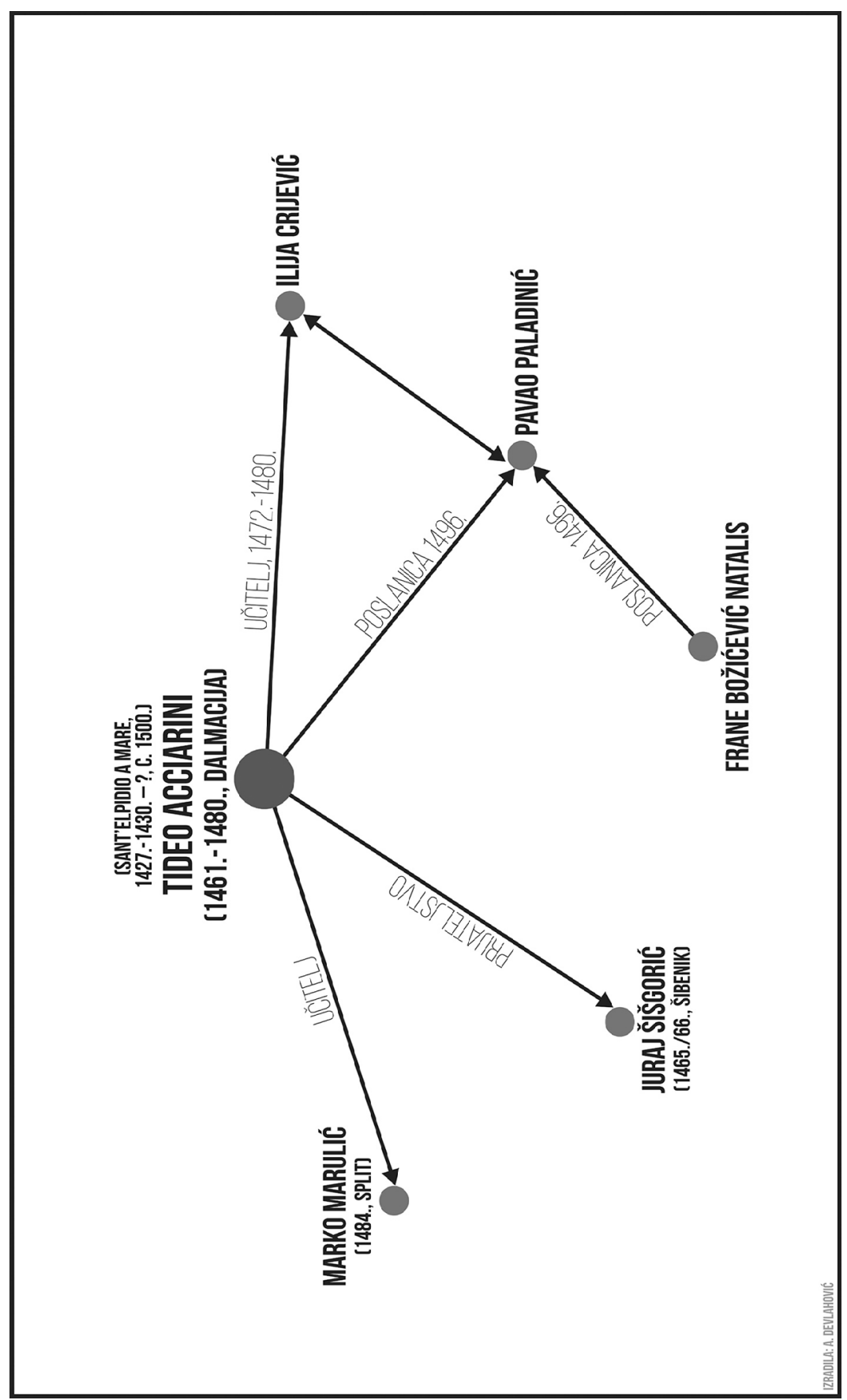

Karta 1. Humanističko (latinističko) protopolje (?): sudionici (članovi) 


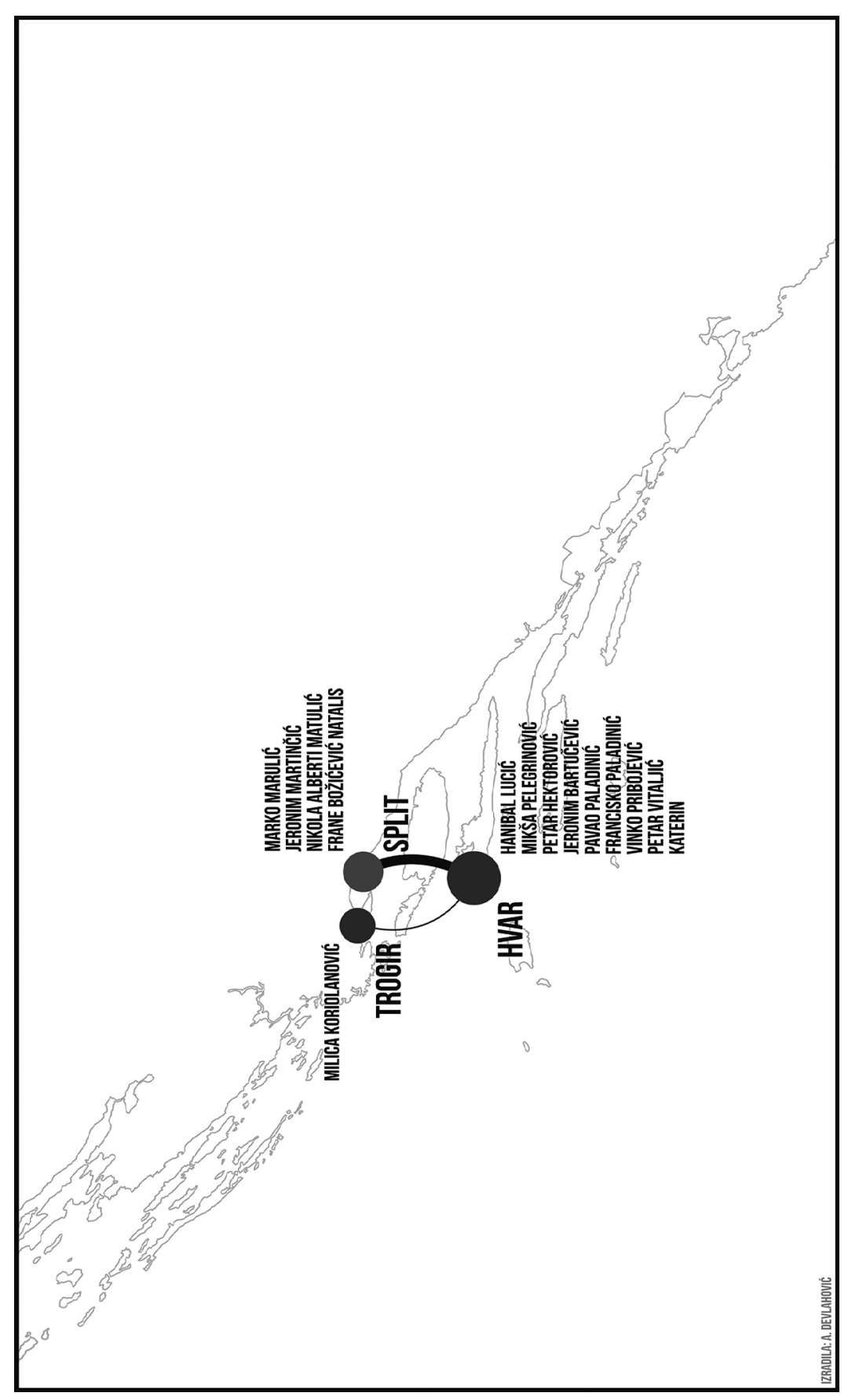

Karta 2. Prvo hvarsko intelektualno polje (1496. - 1528.): prikaz gradova koji sudjeluju u komunikaciji 


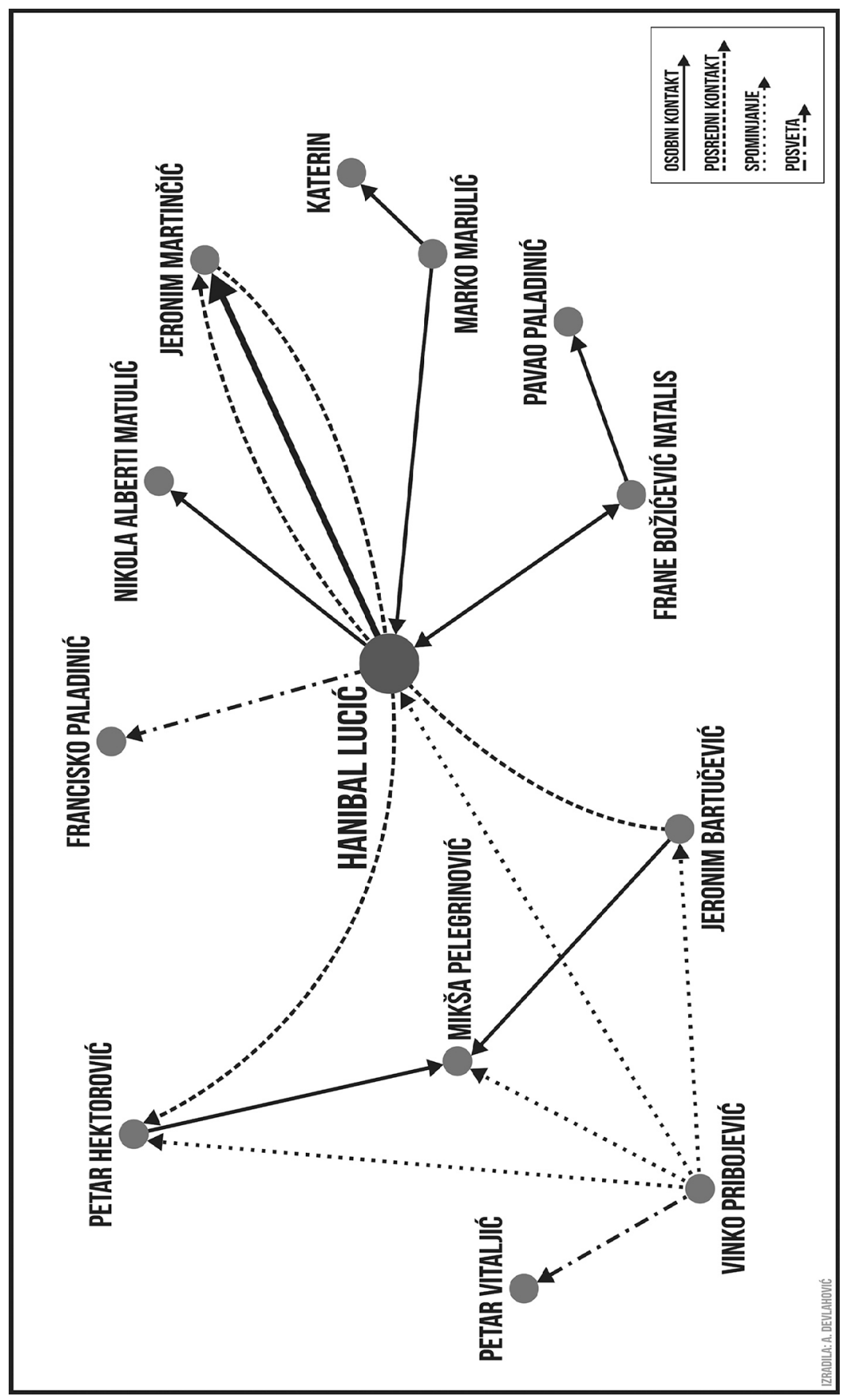

Karta 3. Prvo hvarsko intelektualno polje (1496. - 1528.): sudionici (članovi) 


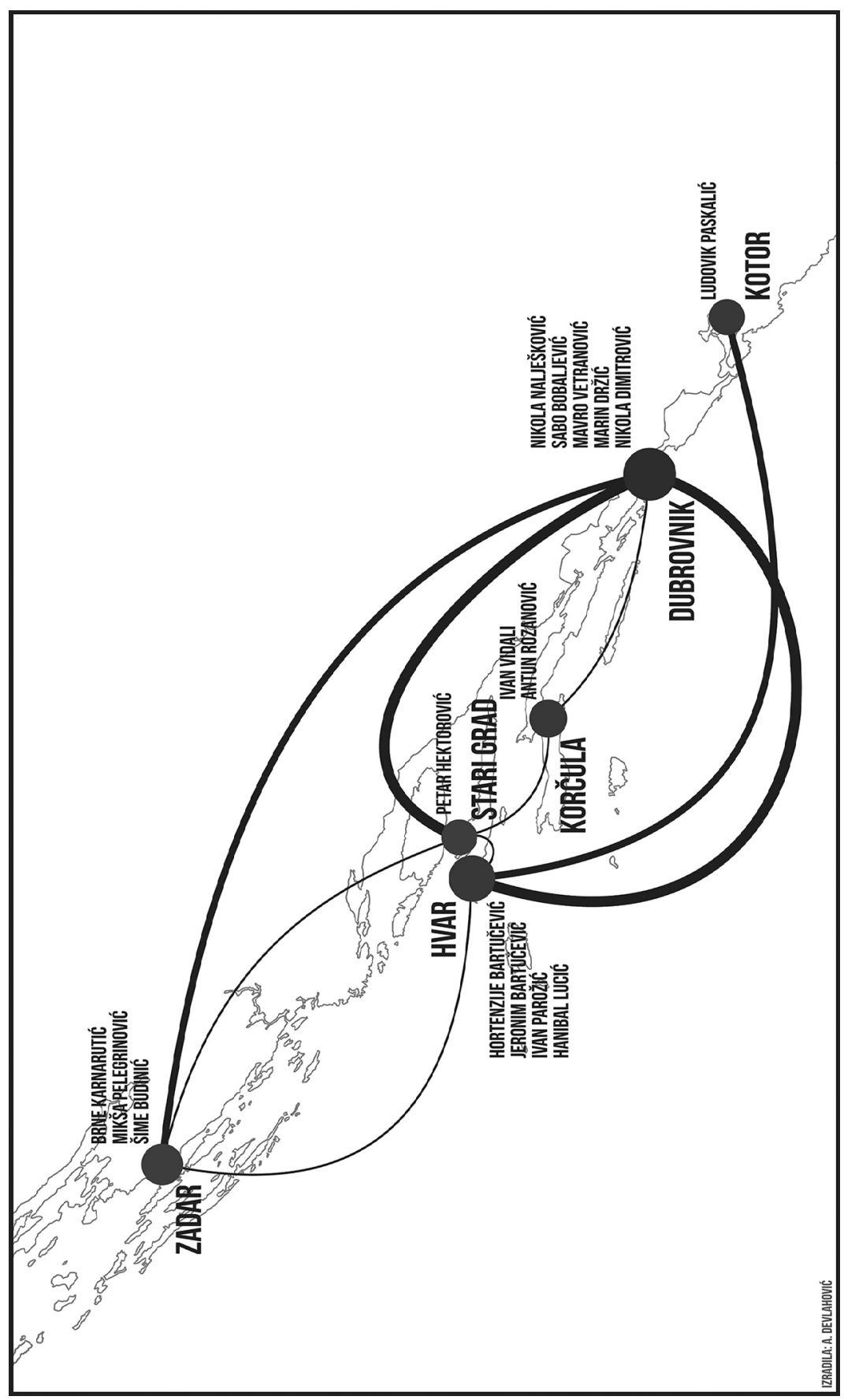

Karta 4. Drugo hvarsko intelektualno polje (1539. - o. 1570.): prikaz gradova koji sudjeluju u komunikaciji 


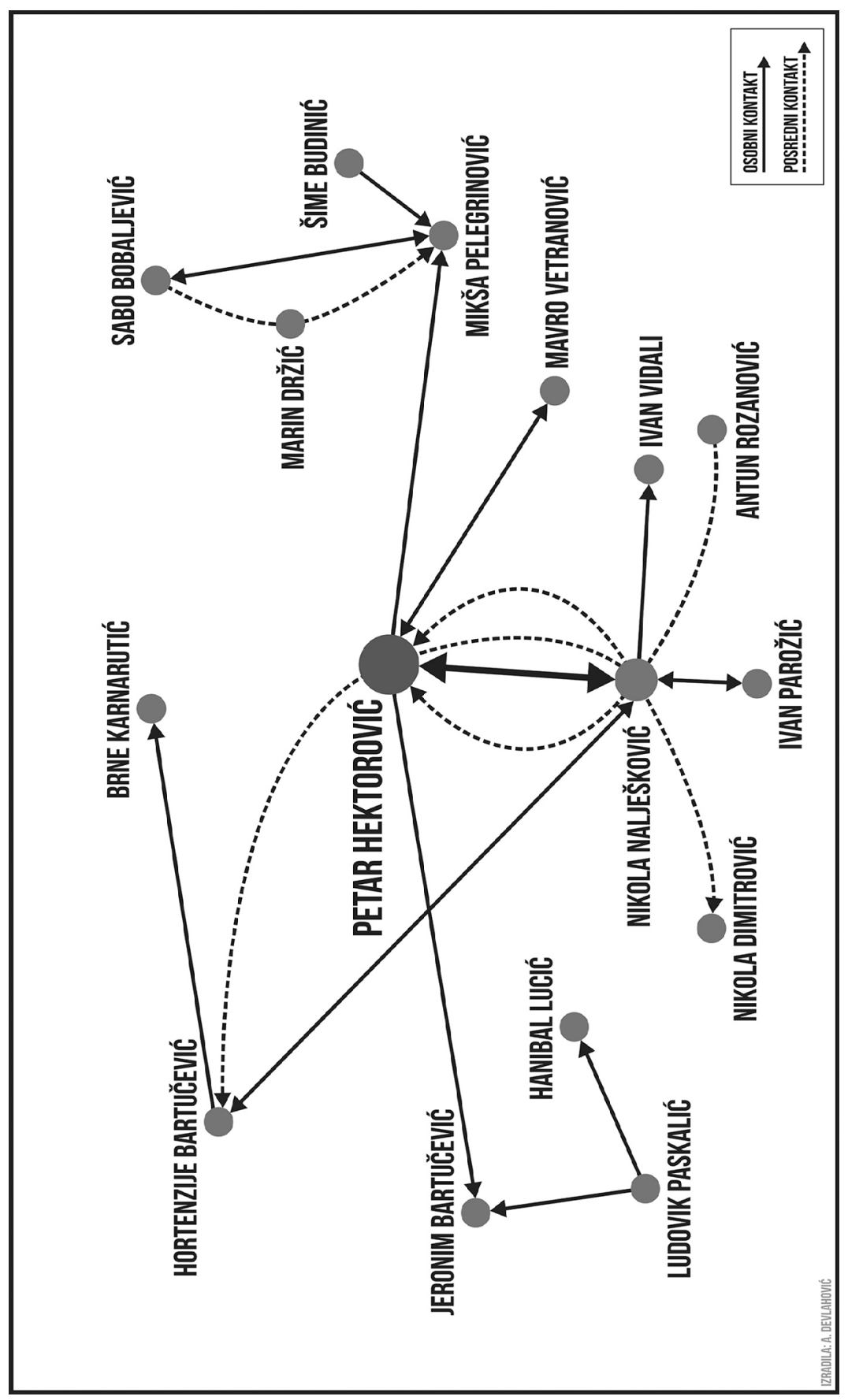

Karta 5. Drugo hvarsko intelektualno polje (1539. - o. 1570.): sudionici (članovi) 


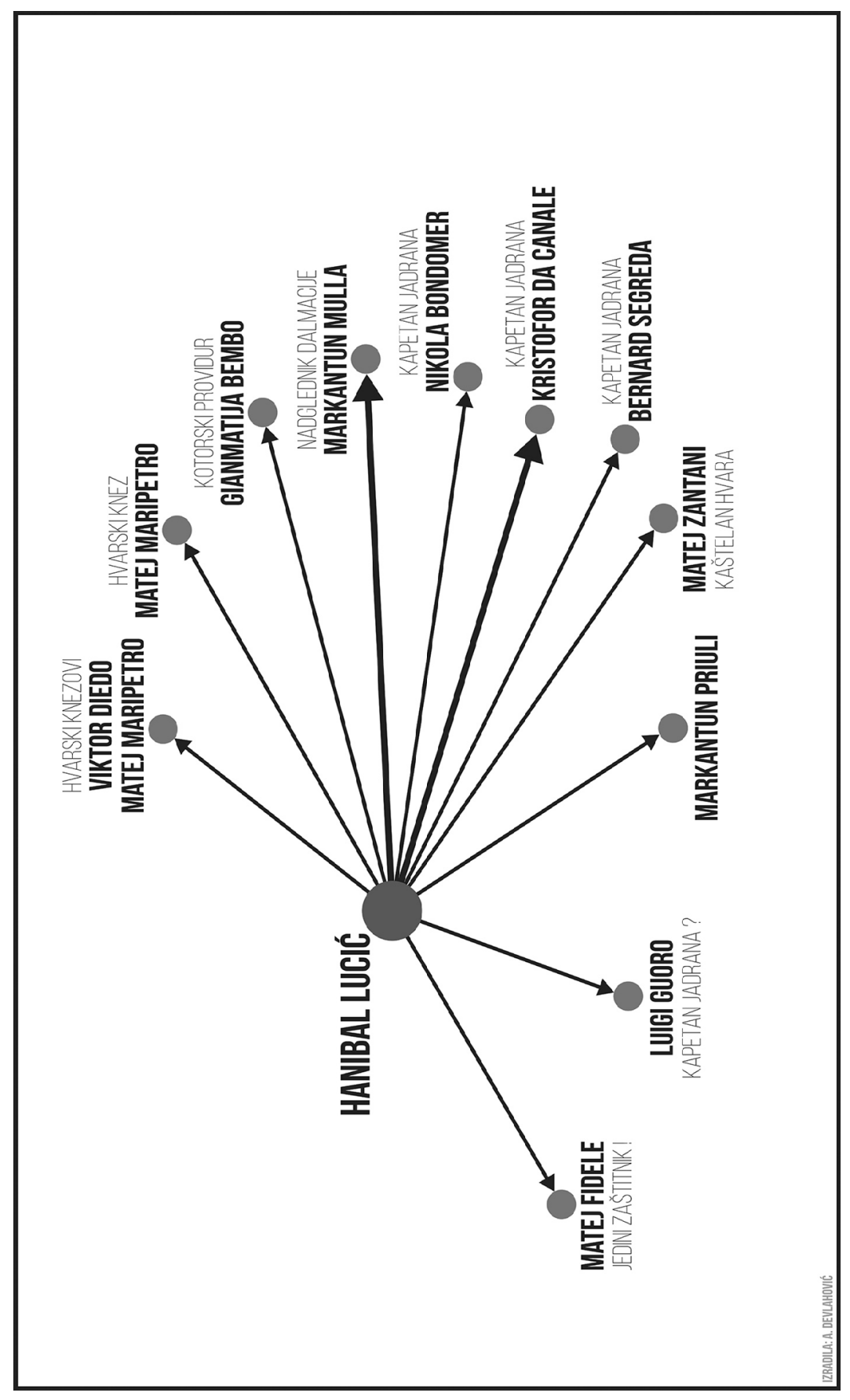

Karta 6. Lucićevi politički soneti upućeni mletačkim uglednicima 


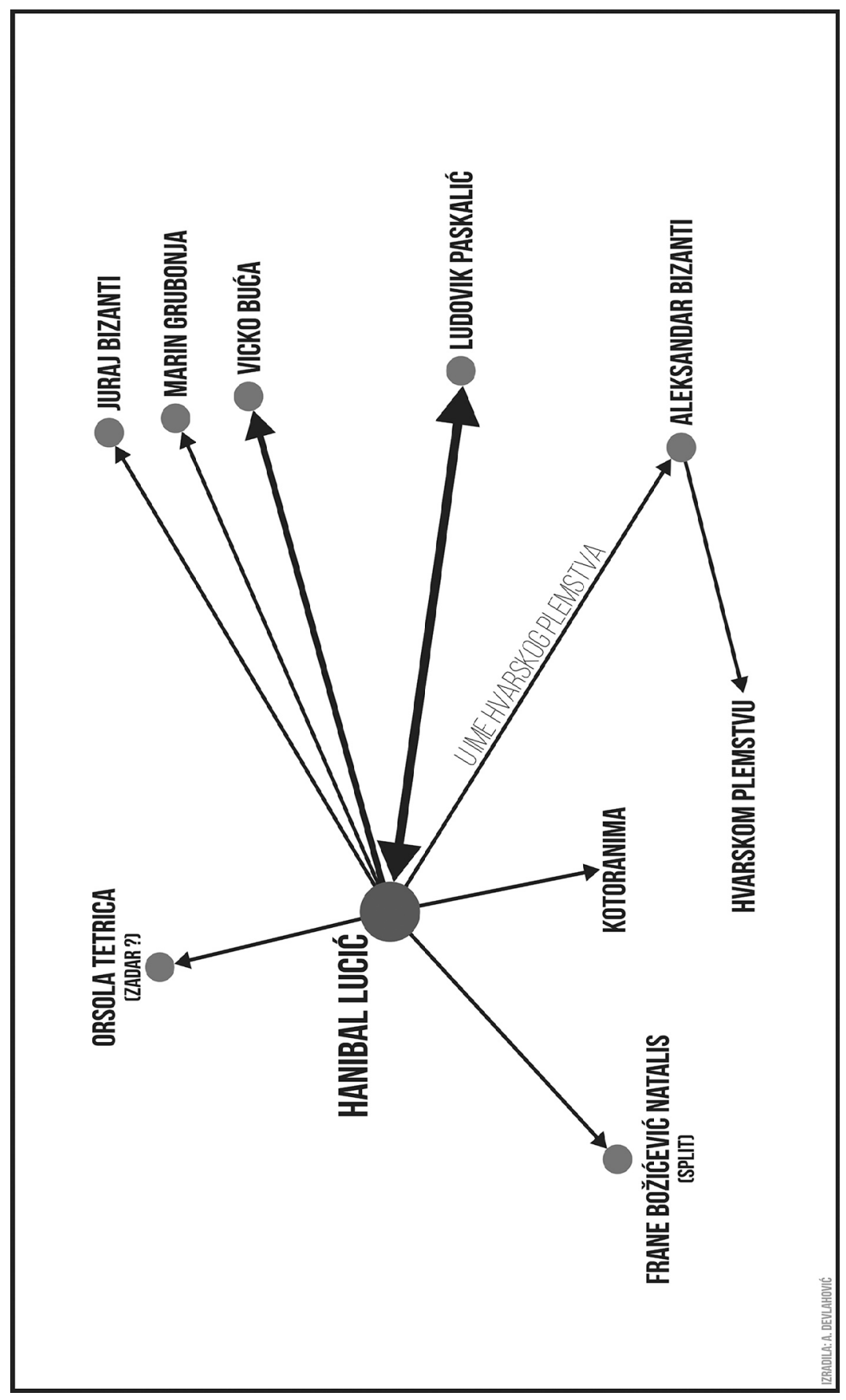

Karta 7. Talijansko intelektualno polje (?): sudionici (članovi) 


\section{SAŽETAK}

\section{Hvarska renesansna intelektualna polja}

Dalmatinske su komune u XVI. stoljeću bile zasebni politički organizmi, strukturirane kao aristokratske republike, a njeni su stanovnici osjećali komunu kao jedinu domovinu. Ipak postojao je i širi društveni prostor u osnovi čijeg su integracijskog procesa bili ljudi, njihove veze i bliskosti duhovnih struktura, a koji se može podijeliti na veći tzv. jadranski društveni prostor koji se ostvaruje na cijelom Jadranu - i hrvatskom i talijanskom, i onaj uži - „istočnojadranski” - u zemlji Schiavona, koji su stvorili svojom intelektualnom djelatnošću, vezama i komunikacijama plemići dalmatinskih komuna, a najočitiji je u kreiranju prostora humanističke i renesansne književnosti, prostor dalmatinske res publica litteraria. Ova „književna republika" nadilazila je uske granice komuna - domovina, ali i staleške podjele unutar komuna - u njoj su ravnopravno sudjelovali književnici plemići i pučani. Kao svaka republika, imala je unutar članova hijerarhijsku ljestvicu i uloge koje su pojedini članovi „republike” zauzimali. Taj društveni prostor dalmatinske književne republike istražen je u svjetlu teorije francuskoga sociologa i filozofa Pierra Bourdieua o intelektualnim i kulturnim poljima, polazeći od premise da su u svakom činu intelektualnog i umjetničkog stvaranja skrivene veze između stvaratelja i njegovoga djela, uvjetovane društvenim odnosima unutar kojih se događa stvaralački čin kao čin komunikacije, odnosno da je samo djelo uvjetovano položajem stvaratelja u intelektualnom polju. Analizirano je 47 komunikacijskih tekstova (prije svega poslanica) napisanih od početka do sedamdesetih godina XVI. st., a kojima su pošiljatelji ili adresati hvarski književnici. Iz toga su proizašla dva hvarska intelektualna polja te uočene centralne ličnosti u svakom od njih. Također je u dodatku, u svjetlu novootkrivene knjige talijanskih soneta Hanibala Lucića, konstruirano Lucićevo talijansko intelektualno polje.

Ključne riječi: Hvar, renesansa, poslanice, dalmatinska res publica litteraria, intelektualna polja 


\section{SUMMARY}

\section{Renaissance intelectual fields of the island of Hvar}

Dalmatian communes in the fifteenth century were discrete political organisms, structured as aristocratic republics, whose inhabitants felt their commune to be their only homeland. There existed, however, a wider social space, the foundation of whose process of integration was based on people, their relationships and the proximity of the structures of their belief systems, which can be divided into a larger, so-called „Adriatic social space” which is achieved over the whole of the Adriatic, both the Croatian and Italian portions, and the narrower „Eastern Adriatic”, in the land of the Schiavona, created by their intellectual activities, relationships and the communication between the nobility from the Dalmatian communes, most evident in the creation of the space of humanist and renaissance literature, the space of the Dalmatian res publice litterarie. This „literary republic" exceeded the narrow borders of the communes, the domovina, and also the class divisions inside the commune, as both noble and popular authors participated in it. Like all republics, among the members existed a hierarchical ladder with roles played by specific members of the „republic”. This social space of the Dalmatian literary republic is researched in light of the theories of French sociologist and philosopher Pierre Bourdieu on intellectual and cultural fields, proceeding from the premise that behind each act of intellectual and artistic creation there lies a hidden relation between the creator and his work, conditioned by the social connections among which the acts of creation and communication are upheld, that is to say, the work itself is conditioned by the position of the creator in his intellectual field. In this paper, 47 communicative texts, for the most part epistles, dating up to the 1570 s are analyzed, whose senders or receivers were Croatian authors. From these, two Croatian intellectual fields emerge, whose central actors are recognized. In the addendum, in the light of the newly discovered book of sonnets in Italian written by Hanibal Lučić, a construction of Lučić's Italian intellectual field has been made.

Keywords: Hvar, Renaissance, epistles, Dalmatian res publica litteraria, intelectual fields 